Национальные клинические рекомендации:

\title{
ТРАНСПЛАНТАЦИЯ ПОЧКИ
}

Кодирование по МКБ-10: N18.0, N04.0

Профессиональная ассоциация: Общероссийская общественная организация трансплантологов «Российское трансплантологическое общество»

Год переутверждения (частота пересмотра): 2016 (каждые 3 года) ID:

URL: 


\section{Оглавление}

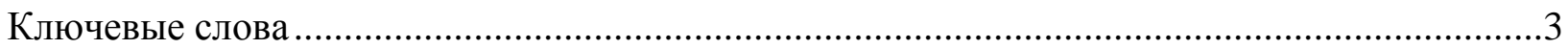

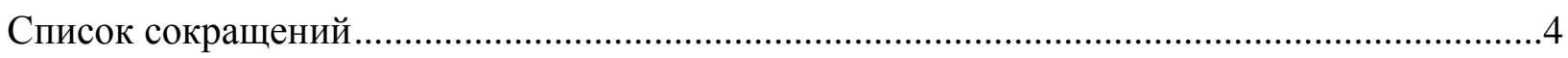

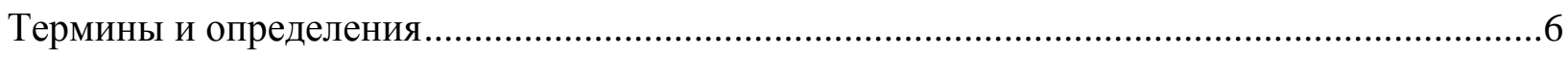

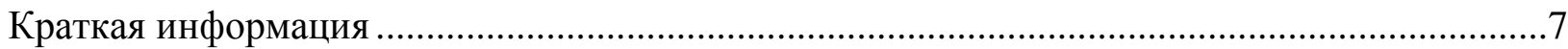

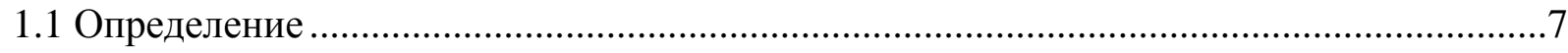

1.2.Этиология и патогенез........................................................................................

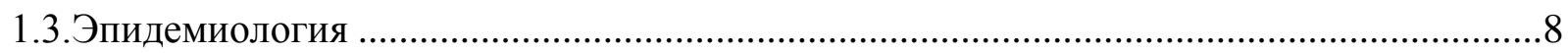

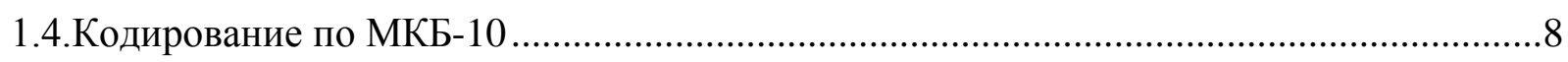

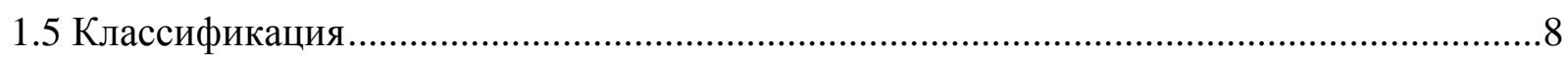

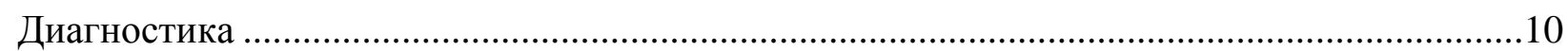

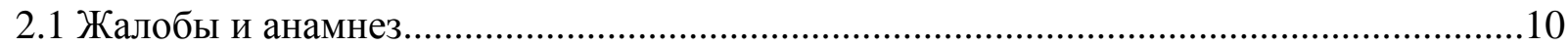

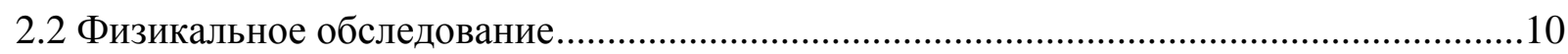

2.3. Лабораторная диагностика................................................................................12

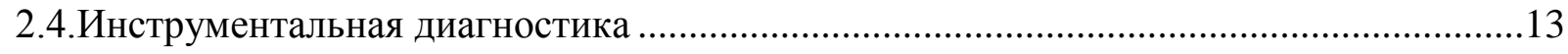

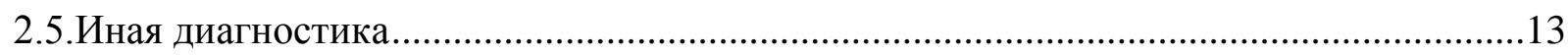

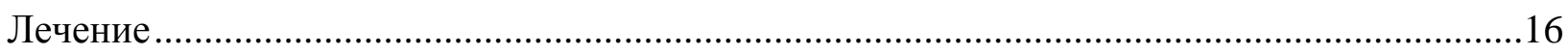

3.1.Консервативное лечение ................................................................................16

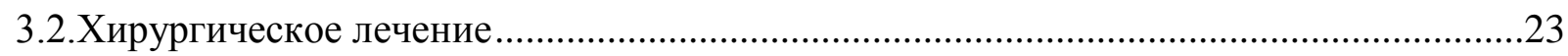

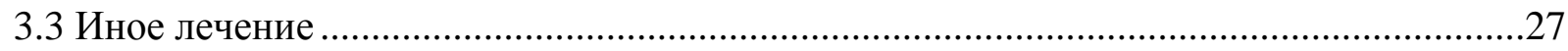

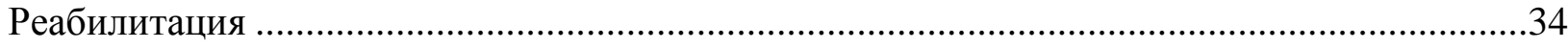

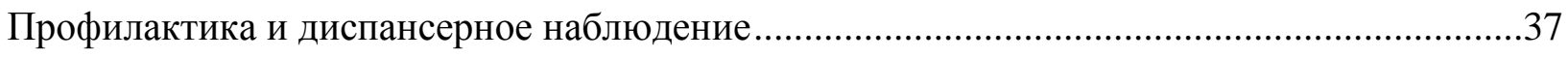

Критерии оценки качества медицинской помощи .............................................................

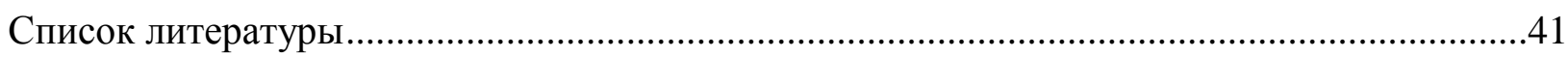

Приложение А1. Состав Рабочей группы ..........................................................................43

Приложение А2. Методология разработки клинических рекомендаций ……………………...45

Приложение А3. Связанные документы ...........................................................................46

Приложение Б. Алгоритмы ведения пациента …………………………………………........48 


\section{Ключевые слова}

Трансплантация почки, родственная трансплантация почки, хроническая почечная недостаточность, заместительная почечная терапия, пересадка почки. 


\section{Список сокращений}

АД - артериальное давление

АЛТ - аланинаминотрансфераза

ACT - аспартатаминотрансфераза

АЧТВ - активированное частичное тромбопластиновое время

ВИЧ - вирус иммунодефицита человека

ВЭБ - водно-электролитный баланс

ГД - гемодиализ

ГКС - глюкокортикостероиды

ДВС - диссеминированное внутрисосудистое свертывание

ДНК (DNA) - дезоксирибонуклеиновая кислота

ЖКТ - желудочно-кишечный тракт

ИВЛ - искусственная вентиляция легких

ИМТ - индекс массы тела

ИФН - интерферон

КЩС - кислотно-щелочное состояние

ЛДГ - лактатдегидрогеназа

MHO - международное нормализованное отношение

МРТ - магнитно-резонансная томография

МСКТ - мультиспиральная компьютерная томография

НПР - неблагоприятные побочные реакции

ОПН - острая почечная недостаточность

ОРВИ - острая респираторная вирусная инфекция

ОРИТ - отделение реанимации и интенсивной терапии

ПТВ - протромбиновое время

ПТИ - протромбиновый индекс

ПЦР - полимеразная цепная реакция

РНК - рибонуклеиновая кислота

СД - сахарный диабет

СЗП - свежезамороженная плазма

СКФ - скорость клубочковой фильтрации

СПИД - синдром приобретенного иммунодефицита

СОЭ - скорость оседания эритроцитов

СРБ - С-реактивный белок

УЗИ - ультразвуковое исследование 
ХБП - хроническая болезнь почек

ХПН - хроническая почечная недостаточность

ЦВК - центральный венозный катетер

ЦМВ (CMV) - цитомегаловирус

ЧДД - частота дыхательных движений

ЧСС - частота сердечных сокращений

ЭГДС - эзофагогастродуоденоскопия

ЭКГ - электрокардиография

ЭМОЛТ - эритроцитарная масса, обедненная лейкоцитами и тромбоцитами

Эхо-КГ - эхокардиографическое исследование

анти-HLA - антитела против антигенов системы HLA

EBV - вирус Эпштейна-Барр

$\mathrm{HAV}$ - вирус гепатита A

HBV - вирус гепатита B

$\mathrm{HCV}$ - вирус гепатита C

$\mathrm{HEV}$ - вирус гепатита E

HSV - вирус простого герпеса

$\mathrm{HZV}$ - вирус опоясывающего герпеса (герпеса зостер)

HLA - лейкоцитарный антиген человека

$\mathrm{IgG}$ - иммуноглобулин $\mathrm{G}$

MELD - шкала Model for End-stage Liver Disease

MRSA - метициллин-резистентный золотистый стафилококк

RAI - rejection activity index (индекс активности отторжения)

$\mathrm{SpO}_{2}$ - сатурация кислорода 


\section{Термины и определения}

Трансплантация почки - хирургическая операция, метод заместительной почечной терапии, заключающаяся в пересадке человеку почки, полученной от другого человека.

Живой родственный донор - лицо, прошедшее обследование и признанное годным к нефрэктомии, находящееся в кровной связи с реципиентом.

Реципиент трансплантированной почки - пациент, у которого была выполнена трансплантация почки.

Отторжение трансплантированной почки- патологический процесс, при котором иммунная система реципиента распознает почечный трансплантат как чужеродный объект, и активируется система гуморального и/или клеточного воспалительного ответа, что может привести к выраженной дисфункции органа.

Потенциальный реципиент почки - пациент с показаниями к трансплантации почки, включенный в лист ожидания.

Хроническая болезнь почек - повреждение почек либо снижение их функции в течение 3 месяцев и более. Заболевание классифицируется на 5 стадий, которые различаются по тактике ведения больного и риску развития терминальной почечной недостаточности и сердечно-сосудистых осложнений. 


\section{Краткая информация}

Трансплантация почки имеет более чем полувековую историю. За этот период накоплен колоссальный опыт, касающийся модернизации хирургической техники, консервации органов, совершенствования и оптимизации протоколов иммуносупрессии, а также послеоперационного ведения пациентов [1]. Уже к концу 90-х годов были достигнуты современные показатели выживаемости почечных трансплантатов и реципиентов. Успехи трансплантации почки, тем не менее, привели к тому, что «листы ожидания» на операцию ежегодно неуклонно растут во всем мире [2].

Помимо низких показателей, определяющих качество жизни, пациенты на заместительной диализной терапии имеют значительно меньшую прогнозируемую продолжительность жизни. Так, пациенты, получающие гемодиализ в возрасте 40-59 лет, живут в среднем на 11 лет меньше по сравнению с теми, кому выполнена трансплантация. Для больных, находящихся в возрастной группе 20-39 лет эта разница составляет уже 17 лет. Прогрессирующий дефицит донорских органов привел к тому, что с целью увеличения количества проводимых операций в последнее время повсеместно наблюдается тенденция к развитию прижизненного донорства $[3,4]$.

\section{1 Определение}

В данных рекомендациях представлено описание технологий оказания медицинской помощи, предполагающей проведение обследований с целью выбора тактики ведения больных почечной недостаточностью в терминальной стадии, определения показаний для трансплантации почки, очередности для включения больных в лист ожидания, а также стабилизацию клинического состояния и оценку возможности восстановления/реабилитации больного после проведения операции трансплантации почки.

Категория возрастная: взрослые, дети

Пол: любой

Фаза: компенсация/декомпенсация

Стадия: терминальная

Осложнения:

Вид медицинской помощи:

Условия оказания медицинской помощи: стационарно

Форма оказания медицинской помощи: плановая; неотложная; экстренная

\section{2.Этиология и патогенез}

Наиболее частой причиной хронической болезни почек являются хронические диффузные поражения почечной паренхимы. Тем не менее возрастает число других 
нозологических форм, а именно: сахарный диабет, системные васкулиты, артериальная гипретензия [5].

У пациентов, страдающих сахарным диабетом, показатели летальности выше, а выживаемость трансплантатов в отдаленном периоде ниже, чем в соответствующих группах пациентов с нормальным метаболизмом глюкозы. Тем не менее, наличие сахарного диабета само по себе не служит противопоказанием к трансплантации почки. Более того, продолжительность и качество жизни у пациентов, которым выполняется трансплантация почки или комбинированная трансплантация «почка - поджелудочная железа», выше, чем аналогичные показатели у пациентов на диализе. Таким образом, возможность проведения трансплантации почки должна рассматриваться в отношении каждого пациента, у которого имеется уремия на фоне сахарного диабета, при отсутствии явных противопоказаний (в первую очередь сердечно-сосудистых заболеваний). При наличии у пациентов сахарного диабета I типа предпочтительнее комбинированная трансплантация «почка-поджелудочная железа», поскольку при этом обеспечивается удовлетворительный контроль гликемии и замедление прогрессирования осложнений сахарного диабета [6].

\section{3.Эпидемиология}

Известно, что потребность в трансплантации почки составляет около 40 операций на 1 млн. населения. По данным за 2012 год в России данный показатель составил 5,5 трансплантаций на 1 млн. населения, что отражает ощутимую потребность в донорских органах.

\section{4.Кодирование по МКБ-10}

N18.0 - терминальная стадия поражения почек

N04.0 - нефротический синдром

\section{5 Классификация}

Современная классификация основана на двух показателях — скорости клубочковой фильтрации (СКФ) и признаках почечного повреждения (протеинурия, альбуминурия). В зависимости от их сочетания выделяют пять стадий хронической болезни почек [4].

\begin{tabular}{|l|l|l|}
\hline Стадия & Описание & СКФ, мл/мин \\
\hline 1 & $\begin{array}{l}\text { Признаки нефропатии, } \\
\text { нормальная СКФ }\end{array}$ & $>90$ \\
\hline 2 & $\begin{array}{l}\text { Признаки нефропатии, } \\
\text { легкое снижение СКФ }\end{array}$ & $60-89$ \\
\hline $3 \mathrm{~A}$ & Умеренное снижение СКФ & $45-59$ \\
\hline
\end{tabular}




\begin{tabular}{|l|l|l|}
\hline ЗБ & Выраженное снижение СКФ & $30-44$ \\
\hline 4 & Тяжелое снижение СКФ & $15-29$ \\
\hline 5 & $\begin{array}{l}\text { Терминальная хроническая } \\
\text { почечная недостаточность }\end{array}$ & $<15$ \\
\hline
\end{tabular}

Стадии 3-5 соответствуют определению хронической почечной недостаточности (снижение СКФ 60 и менее мл/мин). Стадия 5 соответствует терминальной хронической почечной недостаточности (уремия) 


\section{Диагностика}

Обследование больных хронической почечной недостаточностью в качестве потенциальных реципиентов трансплантированной почки.

\section{1 Жалобы и анамнез}

1. Окончательное решение о выборе метода лечения терминальной почечной недостаточности принимается консилиумом врачей-специалистов клинического центра, в котором планируется выполнение хирургического лечение;

Степень доказанности: C.

\section{2 Физикальное обследование}

1. Консультации врачей специалистов в стационаре: кардиолога, анестезиолога-реаниматолога, сердечно-сосудистого хирурга, радиолога, стоматолога. Степень доказанности: C.

2. Консультации врачей-специалистов: эндокринолога, нефролога, инфекциониста, уролога. Степень доказанности: С.

В связи с рисками, связанными с хирургическим вмешательством, анестезией и посттрансплантационной иммуносупрессивной терапией, показано заблаговременное и тщательное обследование потенциальных реципиентов (наиболее пристальное внимание следует уделить оценке состояния сердечно-сосудистой системы). Подобная тактика позволяет уменьшить частоту случаев потери трансплантата, обусловленных техническими причинами, и увеличить показатели выживаемости пациентов в посттрансплантационном периоде.

Зачастую смертность у субъектов, которым была выполнена трансплантация почки, обусловлена заболеваниями сердца. Тем не менее, выживаемость пациентов с уремией и сердечно-сосудистыми изменениями выше после трансплантации почки, чем у находящихся на диализе. Однако стоит отметить, что у пациентов с кардиальной патологией отмечается более высокий периоперационный риск [7]. При наличии в анамнезе у потенциальных реципиентов ишемической болезни сердца, облитерирующего атеросклероза периферических артерий, выраженного атеросклеротического поражения сосудов головного мозга, длительного периода почечной недостаточности и длительного диализа, а также в отношении пожилых пациентов и лиц, страдающих сахарным диабетом, показано детальное обследование сердечно-сосудистой системы.

При наличии выраженного атеросклеротического поражения тазовых сосудов трансплантация может быть противопоказана в связи с большим риском потери трансплантата по техническим причинам и увеличением риска ампутации конечности. Атеросклеротическое поражение церебральных артерий способно приводить к 
увеличению послеоперационных осложнений и летальности реципиентов на фоне нарушения мозгового кровообращения.

У пациентов с избыточной массой тела отмечается более высокая частота хирургических и нехирургических осложнений [3]. Ожирение является традиционным фактором риска развития сахарного диабета, артериальной гипертензии и сердечнососудистых заболеваний. Тем не менее, трансплантация почки позволяет увеличить продолжительность и качество жизни диализных пациентов с избыточной массой тела. На сегодняшний день противопоказания к трансплантации органов исключительно на основании отклонений индекса массы тела (ИМТ) от нормы не являются объективными.

Нарушения в системе свертывания крови увеличивает риск потери трансплантата (вследствие тромбоза сосудов трансплантата, а также тромботических осложнений после трансплантации). Профилактика тромбоза трансплантата в раннем периоде после пересадки донорского органа может обеспечиваться с помощью ранней посттрансплантационной антикоагулянтной терапии. Таким образом, заблаговременно до выполнения трансплантации рекомендуется диагностировать имеющиеся нарушения в системе свертывания крови, в особенности у пациентов с повторными тромбозами сосудистых шунтов или при наличии в анамнезе тромботических осложнений. На фоне иммуносупрессивной терапии после выполнения трансплантации может отмечаться обострение течения некоторых заболеваний и патологических состояний, что, в свою очередь, может приводить к возникновению жизнеугрожающих осложнений. Характерными примерами служат дивертикулез (с ранее отмечавшимися эпизодами дивертикулита или без них), желчекаменная болезнь, гиперпаратиреоз. Предтрансплантационная тактика в подобных случаях должна определяться коллегиально (с участием специалистов различного профиля), а также с учетом особенностей конкретно взятого клинического случая.

На сегодняшний день специалисты единогласно считают, что трансплантация почки позволяет увеличить продолжительность и улучшить качество жизни сравнительно молодых пациентов с терминальной фазой почечной недостаточности. Что касается перспектив трансплантации донорских почек пожилым реципиентам, то на данный счет мнения расходятся.

Умственная отсталость и психические заболевания не являются противопоказаниями к трансплантации донорских органов [8]. Трансплантация может проводиться, если пациент способен к адекватному восприятию необходимых процедур и терапии. 
Гистологические признаки рецидива исходного заболевания нередко отмечаются в трансплантатах. Несмотря на возможность рецидивирования некоторых заболеваний почек, суммарный 10-летний риск потери трансплантата от возвратного заболевания не превышает $10 \%$. Более высокая частота наблюдений возврата заболеваний при трансплантации от живых родственных доноров, особенно раннее их развитие, требует дальнейшего изучения и обсуждения.

Заболевания почек, характеризующиеся высокой частотой рецидивирования, приводящей к ранней потере трансплантата, являются противопоказанием к пересадке почки. К соответствующей группе нозологий относятся болезнь Вальденстрема, первичный оксалоз, а также антигломерулярные антительные реакции (сопровождающиеся образованием антител к базальным мембранам гломерул) [9]. Тем не менее, в ряде ситуаций выполнение трансплантации возможно.

При наличии у пациентов системных заболеваний (например, системной красной волчанки, васкулита, гемолитико-уремического синдрома) рекомендуется лечение фонового заболевания с целью достижения фазы ремиссии на момент трансплантации

В отношении большинства пациентов с гломерулонефритом не имеется специальных рекомендаций.

\section{3. Лабораторная диагностика}

для подтверждения этиологии, определения тяжести заболевания, определения скорости клубочковой фильтрации (СКФ); вирус гепатита В, гепатита С, Эпштейна-Барр, цитомегаловирус, ВИЧ;

- Клинический анализ крови (количество эритроцитов, тромбоцитов, лейкоцитов, определение лейкоцитарной формулы, уровень гемоглобина);

- Биохимический анализ крови (определение уровня общего билирубина и его фракций, общего белка и альбумина, глюкозы, холестерина, креатинина, мочевины, активности щелочной фосфатазы, гамма-ГТ, АСТ, АЛТ, уровня кальция, фосфора, железа);

- Коагулограмма (уровень фибриногена, антитромбина-III, плазминогена, протромбиновый индекс, АЧТВ);

- Исследование кислотно-щелочного состояния, газового и электролитного состава крови;

- Определение группы крови и резус-фактора;

- Вирусологические исследования (маркеры гепатитов В, С, ВИЧ, ПЦР ДНК цитомегаловируса, вируса Эпштейна-Барр); реакция Вассермана;

- Иммунологическое обследование: HLA-типирование (определение антигенов главного комплекса гистосовместимости I и II классов; проводится как реципиентам, так и 
потенциальным родственным донорам), перекрестная лимфоцитотоксическая проба с кровью потенциальных родственных доноров.

\section{4.Инструментальная диагностика}

УЗИ органов брюшной полости (наличие кровотока по воротной вене); Томография органов брюшной полости для определения сосудистой анатомии, диагностики новообразований, тромбоза воротной вены; ЭКГ, ЭхоКГ, а также холтеровское мониторирование, пробы с нагрузкой, коронарография по показаниям, спирометрия Большинство трансплантационных центров при определении возможностей изъятия почки у ЖД применяют расширенные критерии отбора. В результате обследований может быть выявлена та или иная патология, не являющаяся основанием для того, чтобы отвергнуть кандидата. Во многом это определяется опытом и подходами конкретной клиники. В настоящее время имеется общая тенденция к сокращению противопоказаний к донорству, пересмотру значимости различных факторов риска как для донора, так и для реципиента. Чаще всего обнаруживаются умеренная артериальная гипертензия, незначительная протеинурия, избыточный вес, снижение СКФ, различные аномалии и варианты развития почек, эссенциальная гипербилирубинемия.

\section{5.Иная диагностика}

В отношении пациентов, у которых терминальная почечная недостаточность обусловлена врожденными (например, задний уретральный клапан, spina bifida, синдром недостаточности мышц живота, пузырно-мочеточниковый рефлюкс, экстрофия мочевого пузыря) или приобретенными (сморщенный или нейрогенный мочевой пузырь) мальформациями нижних отделов мочевыводящей системы, наиболее оправданной является тактика коррекции мальформации до выполнения трансплантации.

\section{Злокачественные новообразования}

Наличие активного онкологического процесса является противопоказанием к выполнению трансплантации органов, поскольку течение основного заболевания (в данном случае злокачественного новообразования) может ухудшаться на фоне иммуносупрессивной терапии, тем самым угрожать жизни пациента и ставить под сомнение успешность трансплантации. При наличии у пациентов в анамнезе злокачественных новообразований настоятельно рекомендуется перед проведением трансплантации добиться контроля онкологического процесса.

Инфекционные процессы - наиболее грозные потенциальные осложнения после выполненной трансплантации, особенно на фоне проведения интенсивной иммуносупрессивной терапии. Таким образом, до выполнения трансплантации показано 
проведение скрининга с целью исключения активных инфекционных процессов, угрожающих успешности трансплантации [10].

\section{Рекомендации}

- Для увеличения показателей выживания трансплантатов и пациентов после выполненной трансплантации целесообразно заблаговременное и тщательное обследование пациентов в предоперационном периоде (II-B);

- При наличии заболеваний мочеполовой системы обязательным условием является тщательное обследование пациента перед выполнением трансплантации почки (первостепенное значение имеет оценка состояния уродинамики) (II-C);

- При наличии аутосомно-доминантного синдрома поликистозных почек, а также при наличии определенных условий (недостаточное пространство для трансплантации, наличие осложнений, хронических инфекционных процессов, подозрений на злокачественные новообразования) имеются показания для предтрансплантационной или одномоментной нефрэктомии (II-C);

- Активный инфекционный процесс, который может представлять собой угрозу для жизни реципиента после проведенной трансплантации, является противопоказанием к трансплантации(II-B);

- $\quad$ Все кандидаты для трансплантации должны пройти скрининг с целью идентификации вирусных и бактериальных инфекций. В частности, необходимо выявить инфекционные процессы, вызванные такими возбуди телями, как HBV, HCV, ВИЧ, ЦМВ и туберкулез (сбор анамнеза и обзорная рентгенография грудной клетки) (II-B);

- С целью профилактики послеоперационных осложнений показано выявление и лечение фоновых заболеваний перед выполнением трансплантации (II-C);

- В отношении пациентов с высоким риском кардиальной патологии настоятельно рекомендуется детальное обследование с целью исключения ишемической болезни сердца (II-B);

- При наличии показаний до проведения трансплантации рекомендуется выполнение реваскуляризации (как хирургической, так и коронарной ангиопластики) (II-B);

- При наличии тяжелых сопутствующих заболеваний или при неадекватном поведении (некомплаентности) потенциального реципиента показано тщательное индивидуальное психологическое обследование (II-B);

- До проведения трансплантации показано тщательное индивидуальное обследование потенциального реципиента с целью выявления атеросклеротического поражения тазовых, периферических и церебральных артерий. Рекомендовано использовать весь необходимый арсенал лечебно- диагностических мероприятий (II-B); 
- Наличие сахарного диабета не является противопоказанием к трансплантации органов. Тем не менее, заблаговременно до выполнения трансплантации целесообразно детальное обследование пациентов (II-B);

- Ожирение не является противопоказанием к трансплантации органов. Тем не менее, до выполнения трансплантации целесообразно детальное обследование пациентов и лечение, направленное на уменьшение массы тела (II-C);

- С целью профилактики ранних послеоперационных тромботических осложнений показано тщательное изучение состояния системы свертывания крови перед выполнением трансплантации у пациентов повышенного риска (II-C);

- Несмотря на то, что сам по себе возраст не является противопоказанием к выполнению трансплантации, целесообразно тщательно взвесить риски и ожидаемую пользу; пациенты должны быть информированы об увеличении вероятности возникновения послеоперационных осложнений в связи с возрастом (II-B);

- Случаи рецидивирования исходного заболевания почек достаточно часты,однако потери трансплантата при этом встречаются редко (II-C);

- Лишь при некоторых редко встречающихся нозологических формах (характеризующихся высокой частотой рецидивирования) трансплантация противопоказана (II-C);

- При наличии риска рецидивирования исходной патологии почек пациент должен быть об этом проинформирован (II-C) ;

- При планировании повторной трансплантации, а также при наличии в анамнезе экстраренальной трансплантации рекомендуется оценить степень иммунологического риска (в том числе провести тщательный анализ титров анти-HLA-антител) (II-C) . 


\section{Лечение}

\section{1.Консервативное лечение}

Предоперационная десенсибилизация реципиента при выполнении АВ0несовместимой трансплантации почки.

Несовместимость по группе крови между потенциальным донором и его реципиентом обусловлена наличием в плазме крови реципиента специфичных к антигенам донора анти-А/В антител. После восстановления кровотока в органе, пересаженном от АВО-несовместимого донора в течение нескольких минут проходит реакция связывания «антиген-антитело», активируется система комплемента, в пересаженный орган мигрируют иммунокомпетентные клетки реципиента. Реакция завершается тромбозом микроциркуляторного русла трансплантата, что приводит к его утрате [11]. Предоперационная десенсибилизация реципиента направлена на удаление эффекторного звена такой иммунологической реакции, т.е. на анти-А или анти-В антитела и клетки их продуцирующие.

Возможные компоненты протокола предоперационной десенсибилизации.

В течение предоперационной десенсибилизации должны быть решены две задачи: снижение уровня анти-А/В антител до безопасного уровня и блокада de novo синтеза этих антител. В Таблице № 1 перечислены все возможные на сегодняшний день фармакологические и эфферентные методы, которые могут применяться в процессе предоперационной подготовки реципиента к АВО-несовместимой трансплантации почки.

Таблица 1. Возможные компоненты протокола десенсибилизации перед АВОнесовместимой трансплантацией почки.

\begin{tabular}{|l|l|l|}
\hline Задача десенсибилизации & $\begin{array}{l}\text { Возможные } \\
\text { методы }\end{array}$ & Комментарий \\
\hline $\begin{array}{l}\text { Снижение уровня анти- } \\
\text { А/В антител }\end{array}$ & $\begin{array}{l}\text { Возмещение потерь белка, факторов } \\
\text { свертывающей системы проводится } \\
\text { свежезамороженной плазмой, полученной } \\
\text { от доноров с АВ(IV) группой крови, так } \\
\text { как такая плазма не содержит ни анти-А, } \\
\text { ни анти-В антител. }\end{array}$ \\
\hline
\end{tabular}




\begin{tabular}{|c|c|c|}
\hline & $\begin{array}{l}\text { Каскадный } \\
\text { плазмаферез }\end{array}$ & $\begin{array}{l}\text { По сравнению с плазмаферезом потери } \\
\text { белка и факторов свертывающей системы } \\
\text { значительно меньше, для их возмещения } \\
\text { используется раствор альбумина. }\end{array}$ \\
\hline & $\begin{array}{l}\text { Неселективная } \\
\text { иммуноадсорбция }\end{array}$ & $\begin{array}{l}\text { Независимо от специфичности из } \\
\text { циркуляции удаляются иммуноглобулины } \\
\text { классов M и G. Белковые потери при } \\
\text { данной процедуре минимальны. }\end{array}$ \\
\hline & $\begin{array}{l}\text { Селективная } \\
\text { иммуноадсорбция }\end{array}$ & $\begin{array}{l}\text { Из циркуляции удаляются только } \\
\text { специфичные к антигену А и/или В } \\
\text { антитела классов IgM и IgG. Белковые } \\
\text { потери при данной процедуре }\end{array}$ \\
\hline \multirow[t]{3}{*}{$\begin{array}{l}\text { Блокада синтеза анти-А/В } \\
\text { антител }\end{array}$} & $\begin{array}{l}\text { Анти-CD20 } \\
\text { моноклональные } \\
\text { антитела } \\
\text { (ритуксимаб) }\end{array}$ & $\begin{array}{l}\text { Препарат вызывает быстрое, но } \\
\text { обратимое истощение пула В- } \\
\text { лимфоцитов, за счет этого угнетается } \\
\text { процесс образования плазматических } \\
\text { клеток и, как следствие, затормаживается } \\
\text { процесс антителообразования. }\end{array}$ \\
\hline & $\begin{array}{l}\text { Сывороточный } \\
\text { человеческий } \\
\text { иммуноглобулин }\end{array}$ & 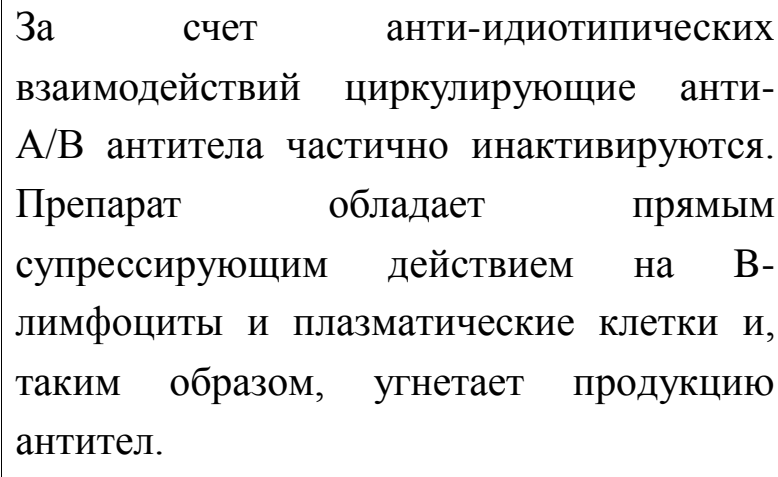 \\
\hline & $\begin{array}{l}\text { Такролимус, } \\
\text { препараты } \\
\text { микофеноловой } \\
\text { кислоты, } \\
\text { глюкокортикостер } \\
\text { оиды }\end{array}$ & 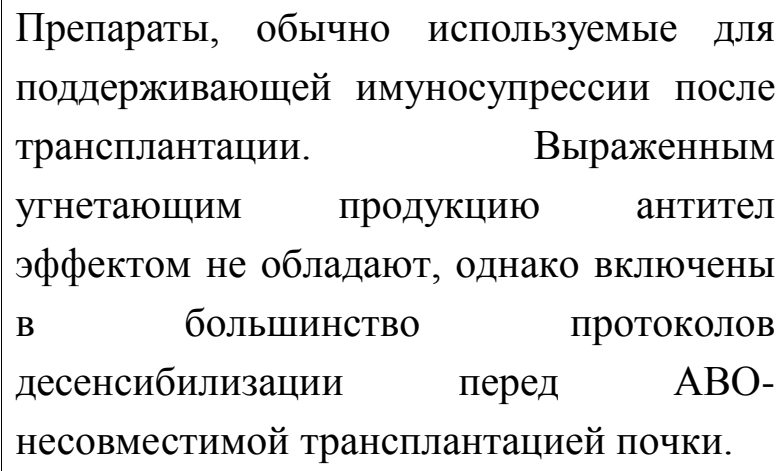 \\
\hline
\end{tabular}




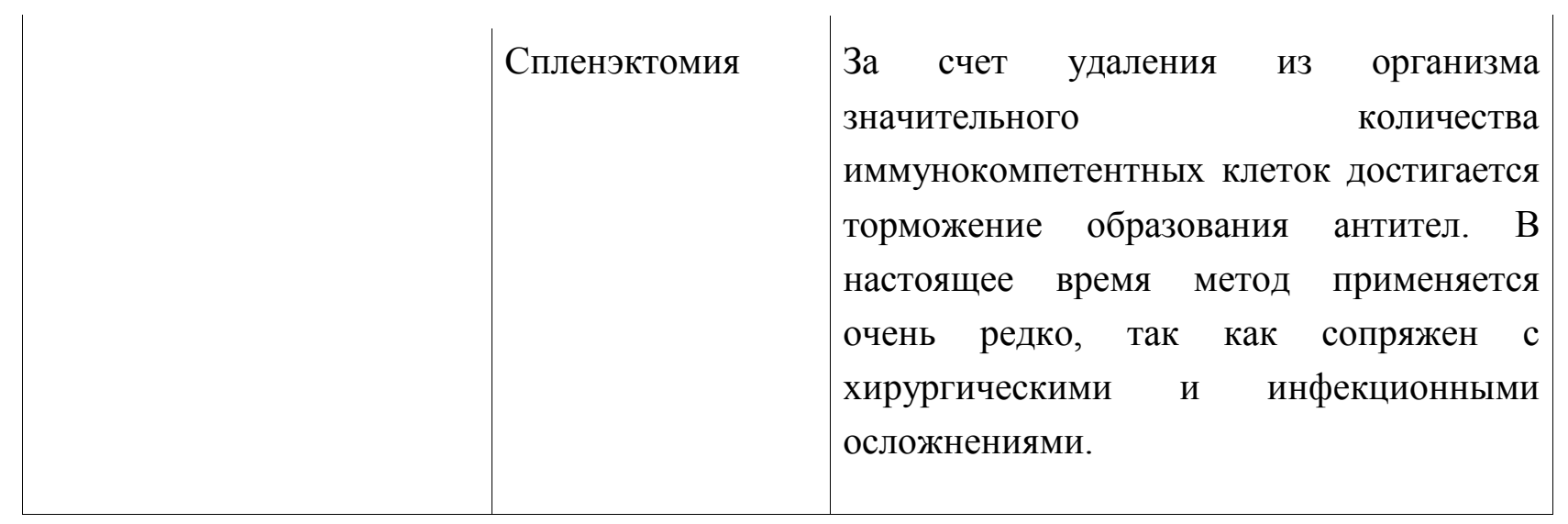

Протокол десенсибилизации перед АВО-несовместимой трансплантацией почки на основе ритуксимаба, плазмаферез/иммуноадсорбции и сывороточного человеческого иммуноглобулина.

Наиболее распространенной в европейских странах является так называемый «Стокгольмский протокол», который включает в себя однократное введение ритуксимаба, сеансы селективной иммуноадсорбции и однократное внутривенное введение сывороточного человеческого иммуноглобулина в высокой дозе. Схема дополняется назначением трехкомпонентной иммуносупрессивной терапии (такролимус + микофенолата мофетил + преднизолон) в предоперационном периоде.

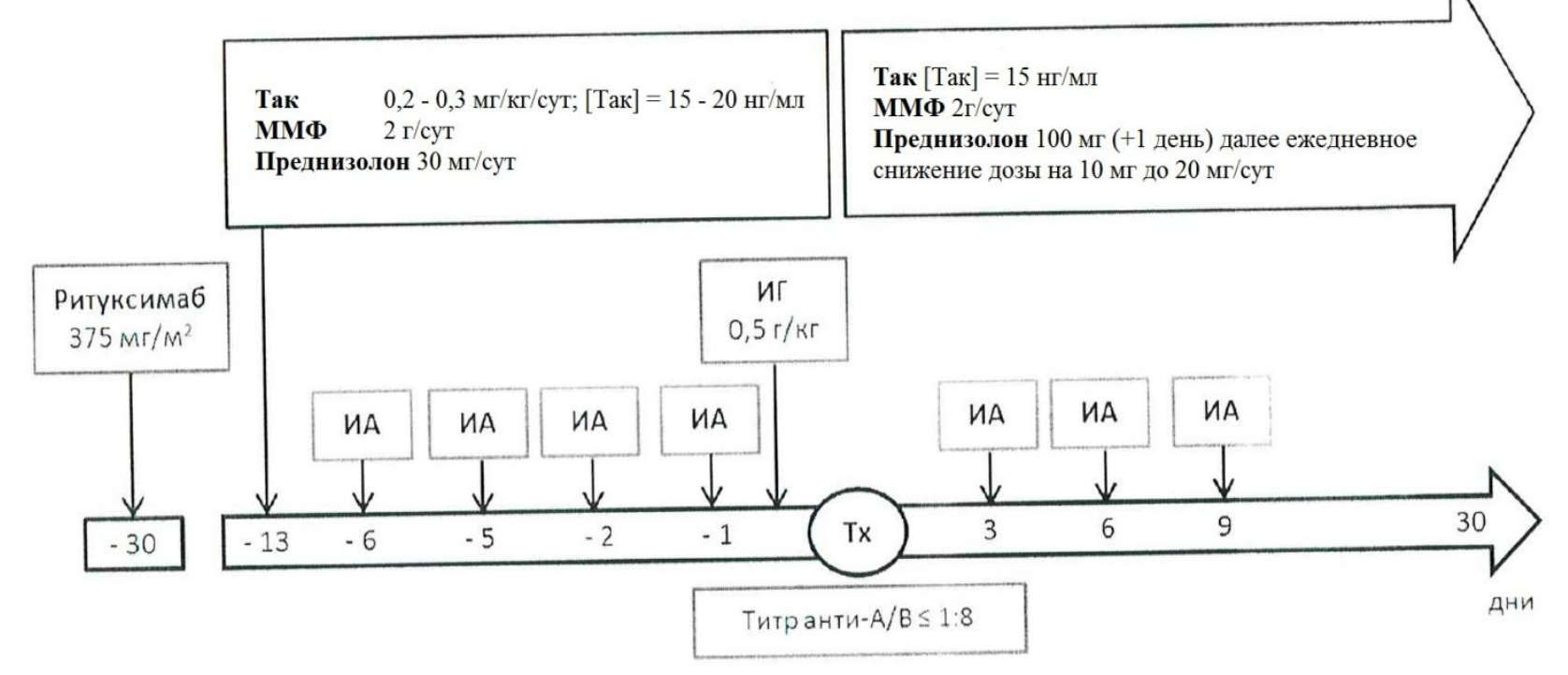

Рисунок 1. «Стокгольмский» протокол проведения $\mathrm{ABO}$-несовместимой трансплантации почки от живого донора. ИА, специфическая иммуноадсорбция; ИГ, сывороточный иммуноглобулин, Тх - трансплантация почки.

Применение препаратов крови и ее компонентов у кандидатов на АВОнесовместимую родственную трансплантацию почки. 
При обследовании, у подавляющего большинства кандидатов на трансплантацию почки выявляется анемия различной степени тяжести. Как правило, применение препаратов железа, фолиевой кислоты и рекомбинантного эритропоэтина позволяет поддерживать концентрацию гемоглобина на приемлемом уровне и не прибегать к гемотрансфузиям. В ходе предоперационной подготовки анемия может усугубляться. При снижении уровня гемоглобина ниже 65-70 г/л пациенту показано переливание отмытых одногруппных эритроцитов.

Проведение эфферентных процедур по удалению анти-А/В антител связано с необходимостью замещения потерь белка и/или факторов свертывающей системы крови. Для этих целей могут быть использованы растворы человеческого альбумина различных концентраций и/или свежезамороженная плазма. Если используется свежезамороженная плазма, то независимо от групп крови потенциального реципиента и его родственного донора, она должна быть AB(IV) группы крови, так как не содержит в себе ни анти-А, ни анти-В антител.

Наряду с прогрессированием анемии, в течение предоперационной подготовки у пациента может развиваться тромбоцитопения. Уровень тромбоцитов более 100 тыс. кл/мл следует считать допустимым и не требующим каких-либо терапевтических вмешательств. При снижении количества тромбоцитов ниже 100 тыс. кл/мл следует редуцировать вдвое дозу или отменить препараты микофеноловой кислоты. При снижении количества тромбоцитов менее 40 тыс. кл/мл следует временно остановить эфферентные процедуры и возобновить их после того, как уровень тромбоцитов станет выше 50 тыс. кл/мл. Показанием к переливанию тромбоконцентрата следует считать уровень тромбоцитов ниже 50 тыс. кл/мл и развившееся кровотечение или спонтанную кровоточивость, геморрагии на коже и видимых слизистых.

Контроль эффективности десенсибилизации и критерии готовности потенциального реципиента к трансплантации.

Единое мнение относительно безопасного, т. е. целевого уровня анти-А/В антител, который должен быть достигнут по окончанию предоперационной подготовки отсутствует. Данный показатель, в зависимости от трансплантационного центра варьирует от 1:4 до 1:32. Большинство центров, в которых регулярно и с хорошими результатами выполняются АВО несовместимые трансплантации, определяют этот уровень как не более 1:8 для антител класса $\operatorname{IgM}$ и IgG. Независимо от выбранного протокола подготовки, контрольными точками, когда должно быть выполнено определение титра анти-А/В антител, следует считать следующие:

- При обследовании на амбулаторном этапе; 
- Перед началом предоперационной подготовки (до введения ритуксимаба);

- Перед каждым сеансом плазмафереза или иммуноадсорбции;

- На следующий день после каждого сеанса плазмафереза или иммуноадсорбции;

- За сутки до трансплантации;

- В день операции, перед подачей пациента и его донора в операционную. Если за сутки или в день, на который назначена трансплантация, титр анти-А/В антител превышает целевое значение или результат анализа сомнителен, то операцию следует отменить и решить вопрос о продолжении десенсибилизации с обязательным дальнейшим контролем уровня антигрупповых антител.

Помимо значений титра анти-А/В антител в каждой контрольной точке, следует учитывать и динамику снижения титра анти-А/В в течение подготовки [4]. Выделяют два характерных профиля снижения:

1) последовательное снижение титра в течение всей подготовки, когда при каждом следующем определении уровень анти-А/В антител по крайней мере не выше предыдущего (Рисунок 2)

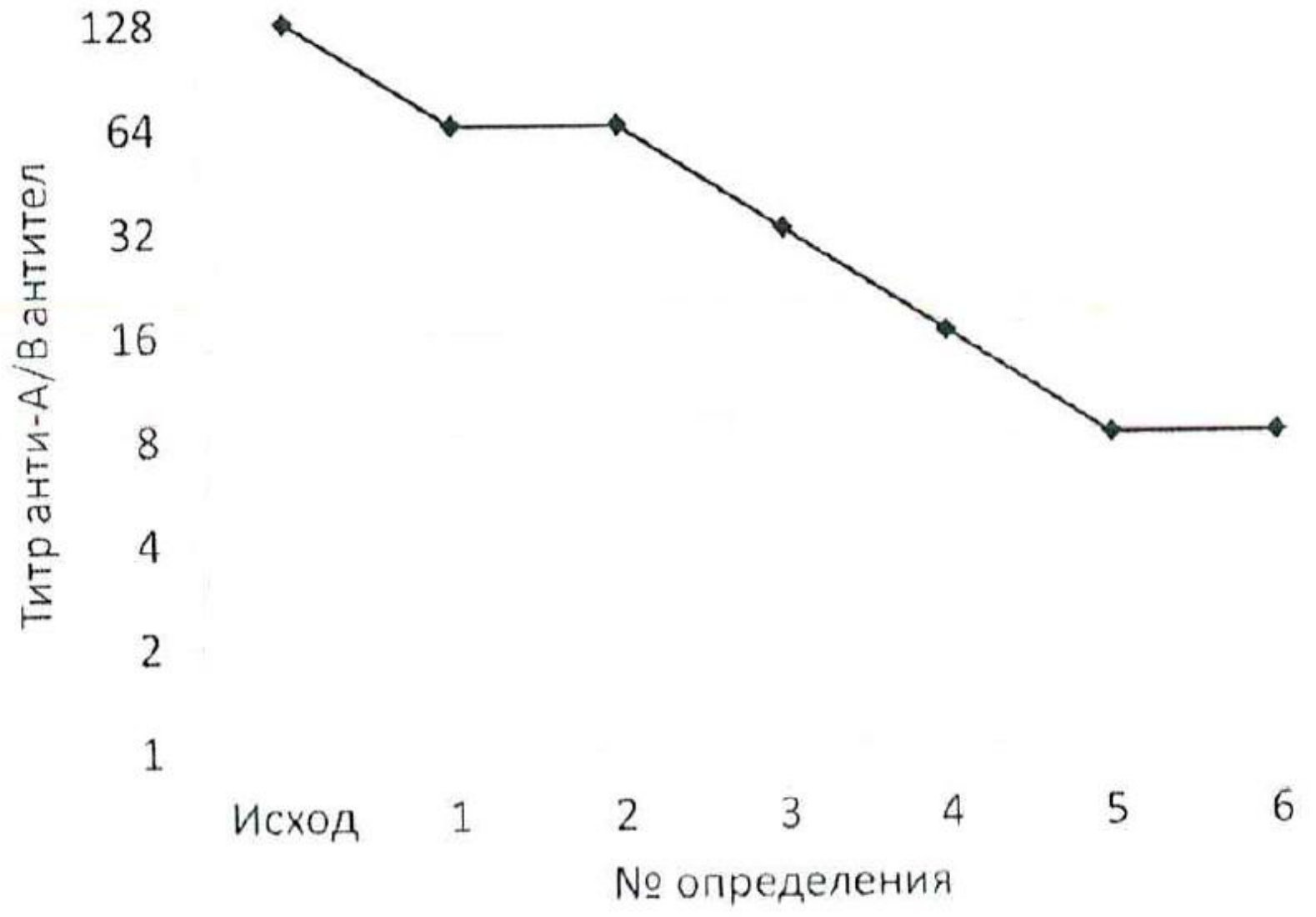

Рисунок 2. Пример последовательного снижения титра анти-А/В антител в течение предоперационной подготовки 
2) «пилообразное» снижение титра, когда уровень анти-А/В антител при последующих измерениях может превышать ранее определенный уровень (Рисунок 3 ).

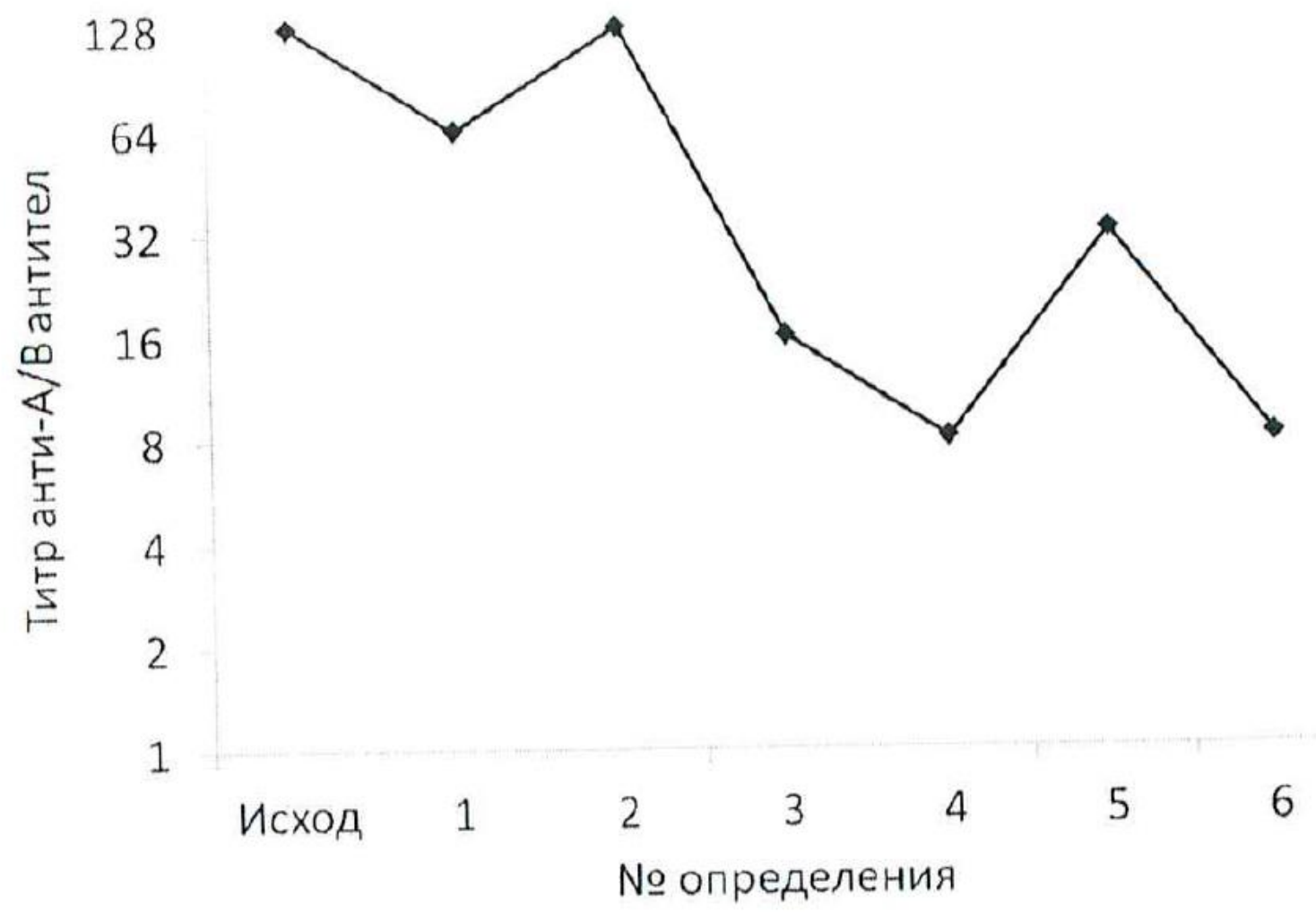

Рисунок 3. Пример «пилообразного» снижения титра анти-А/В антител в течение предоперационной подготовки

Последовательное снижение уровня анти-А/В антител свидетельствует об отсутствии или слабой выраженности эффекта восстановления уровня антител («rebound effect») и является более благоприятной ситуацией, по сравнению с «пилообразным» профилем снижения, когда эффект восстановления выражен значительно сильнее.

При «пилообразном» снижении достижение целевого уровня антител в одном определении не следует рассматривать как готовность пациента к трансплантации. Целесообразными в данном случае можно считать следующую стратегию: перенести дату операции на 3 - 5 дней и проводить ежедневное определение уровня антител, если в течение этого времени титр остается в пределах целевых значений, т.е. не превышает 1:8, то выполнение операции возможно. В случае если отмечается рост антител, следует отложить выполнение операции на более длительный срок и возобновить сеансы плазмафереза или иммуноадсорбции с обязательным контролем титра анти-А/В антител. В ситуации, когда таким образом не удается добиться стойкого снижения антител, десенсибилизацию следует признать неэффективной и отменить трансплантацию.

Если исходный титр анти-А/B антител у кандидата на АВО-несовместимую трансплантацию не превышает 1:4, то возможным является отказ от проведения 
эфферентных процедур. При этом длительность подготовки не должна быть менее 7 дней, в течение которых титр анти-А/В антител должен быть определен не менее 3 раз. В некоторых центрах, за сутки до трансплантации обязательно проводят сеанс плазмафереза даже при отсутствии в плазме крови потенциального реципиента анти-А/В антител.

Рекомендации:

- Протокол подготовки к АВО-несовместимой родственной трансплантации почки должен быть основан на комбинации ритуксимаба, плазмафереза и/или специфической иммуноадсорбции, сывороточного иммуноглобулина и трехкомпонентной иммуносупрессивной терапии. В зависимости от исходного титра анти-А/В антител возможна персонализация схемы кондиционирования;

- На протяжении всей подготовки к ABO-несовместимой трансплантации вплоть до дня операции должен осуществляться регулярный контроль титра анти-А/В антител;

- Целевым (безопасным) уровнем анти-А/В антител, при котором возможно выполнение трансплантации, следует считать 1:8 для антител класса IgG и IgM. По усмотрению трансплантационного центра этот уровень может быть снижен до 1:4 или еще меньше;

- Для восполнения потерь белка, связанных с проведением эфферентных процедур, могут быть использованы растворы альбумина человека различных концентраций и/или свежезамороженная плазма AB(IV) группы крови;

- При необходимости гемотрансфузий кандидату на АВО-несовместимую трансплантацию следует руководствоваться инструкциями Минздрава России (Приказ Минздрава России от 02.04.2013 N 183н "Об утверждении правил клинического использования донорской крови и (или) ее компонентов");

- Критерием готовности пациента к АВО-несовместимой трансплантации следует считать стойкое достижение целевого (безопасного) титра анти-А/В антител;

- Положительная перекрестная проба (cross-match) является абсолютным противопоказанием к АВО-несовместимой родственной трансплантации;

- При отрицательной перекрестной пробе наличие анти-HLA антител, определенных у потенциального реципиента, не является абсолютным противопоказанием к проведению предоперационной подготовки и последующей трансплантации. В зависимости от уровня и специфичности анти-HLA антител протокол десенсибилизации может быть модифицирован с целью их элиминации. АВОнесовместимая трансплантация пациенту, имеющему донор-специфические антиHLA антитела с MFI > 1000 единиц сопряжена с высоким дополнительным риском иммунологических осложнений; 
- Перед началом программы АВО-несовместимых родственных трансплантаций почки должны быть решены все организационные вопросы, проведено обучение сотрудников, решены вопросы обеспечения всего процесса необходимыми медикаментами и расходными материалами.

\section{2.Хирургическое лечение}

Поскольку все реципиенты трансплантата почки получают иммуносупрессивные препараты и многие из них уже имеют анемию и сниженный нутритивный статус, заживление послеоперационной раны может быть скомпрометировано. Необходимыми условиями выполнения трансплантации являются: прецизионная хирургическая техника, внимание к деталям, строжайшая асептика и тщательный гемостаз. Дренажи должны быть закрытыми системами и удаляться так быстро после операции, насколько это возможно.

После профилактического введения антибиотика производится внебрюшинный доступ по Gibson: от симфиза латерально и вверх параллельно паховой связке. При необходимости широкой экспозиции разрез продлевают до нижнего края 12 ребра. Если трансплантация выполняется впервые, то доступ может быть осуществлен как справа, так и слева. Существуют различные подходы к выбору стороны операции. Один из них предполагает выполнение доступа только справа, независимо от того правая или левая почка донора будет пересажена. В этом случае большая доступность правой подвздошной вены, по сравнению с левой облегчает выполнение операции. Другой вариант - это выполнение доступа со стороны, противоположной той, с которой получен трансплантат, то есть правая почка размещается слева и наоборот. Эта техника обычно применяется, когда для анастомоза используется внутренняя подвздошная артерия, так как сосуды находятся в удобной для этого позиции и лоханка обращена к передней брюшной стенке, что делает возможным последующие реконструкции при показаниях, в том числе и на мочеточнике. Третий подход предполагает осуществление доступа на стороне, ипсилатеральной донорской почке: при этом правая почка донора помещается в правой подвздошной области, а левая - слева. Этот способ предпочтителен, если для артериального анастомоза выбирается наружная подвздошная артерия. При этом, когда трансплантат «уложен» в нужную позицию, сосуды лежат без избыточного изгиба. При повторной трансплантации для выполнения доступа обычно выбирается сторона, противоположная стороне предыдущей операции. При дальнейших трансплантациях вопрос о выборе доступа становиться более сложным. Может потребоваться трансабдоминальный доступ. В подобных ситуациях могут быть использованы более проксимально расположенные сосуды. 
У пациентов с сахарным диабетом I типа, которые в перспективе могут стать и реципиентами поджелудочной железы, донорскую почку предпочтительно размещать в левой подвздошной ямке - для облегчения трансплантации поджелудочной железы на правую сторону.

Почечную вену донорской почки обычно анастомозируют с наружной подвздошной веной реципиента по типу «конец в бок». Для анастомоза используют полипропиленовую нить 5-0. При наличии нескольких почечных вен для анастомоза обычно выбирают наибольшую; остальные вены могут быть безопасно перевязаны, так как внутрипочечная сеть венозного оттока имеет множество коллатералей. Если трансплантат имеет две равнозначные вены, они могут быть сшиты между собой по типу «штанов» и далее, одним устьем анастомозированы с подвздошной веной реципиента. Так же возможен вариант, когда две равнозначные почечные вены анастомозируются с наружной подвздошной веной по отдельности. В случае, если трансплантат забран от умершего донора, то короткая правая почечная вена может быть удлинена за счет участка нижней полой вены донора. С целью сокращения ишемии нижней конечности венозный анастомоз обычно накладывают в первую очередь. Почечную артерию трансплантата обычно анастомозируют с наружной подвздошной артерией по типу «конец в бок». Для анастомоза используют полипропиленовую нить 5-0 или 6-0. При трупной трансплантации трансплантаты с почечной артерией или артериями берутся на протяжении с участком аорты - так называемой площадкой Карреля, наличие которой делает выполнение анастомоза по типу «конец в бок» более легким и безопасным и особенно облегчает анастомозирование в случае множественных артерий. При трансплантации от живого донора формирование аортальной площадки невозможно, и к артерии реципиента пришивается собственно почечная артерия трансплантата. У маленьких детей или у пациентов подвергающихся повторной трансплантации на той же стороне может потребоваться доступ к общей подвздошной артерии, аорте или эпигастральной артерии. Во время формирования сосудистых анастомозов для минимизации тепловой ишемии почка должна быть обернута салфеткой с ледяной крошкой.

Предложено большое количество способов формирования сосудистых анастомозов при наличии множественных артерий трансплантата. В любом случае недопустима перевязка нижнеполюсной артерии - это может привести к некрозу мочеточника. Иногда могут быть обнаружены маленькие артерии, идущие к почечной капсуле. Эти сосуды можно безопасно перевязать - в результате на капсуле почки могут появиться незначительные участки ишемии. В случае трансплантации от трупного донора оптимальный вариант - это сохранить все почечные артерии на аортальной площадке и 
вшить ее в артерию реципиента. Если выполняется трансплантация почки от живого донора или по каким-то причинам площадка Карреля отсутствует почечные артерии трансплантата могут быть анастомозированы последовательно, раздельно с сосудами реципиента или между собой перед формированием анастомоза с сосудами реципиента. В некоторых случаях может быть выполнен анастомоз по типу «конец в конец» между небольшой нижнеполюсной артерией трансплантата и нижней надчревной артерией. Иногда при трансплантации почки с множественными артериями перед началом формирования артериальных анастомозов уместно ввести внутривенно болюсно $1000 \mathrm{ME}$ гепарина и далее продолжить внутривенную инфузию гепарина со скоростью $100 \mathrm{ME} /$ в течение всего периода госпитализации.

Мочеточник может быть анастомозирован или с мочевым пузырем реципиента, или с собственным мочеточником. Также собственный мочеточник может быть анастомозирован с 20 лоханкой трансплантата. Большинство хирургов по возможности предпочитает для формирования анастомоза с мочеточником мочевой пузырь реципиента. Предпочтительно, перед трансплантацией оценить функциональное состояние мочевого пузыря реципиента. Однако, как правило, после операции даже маленький, сократившийся мочевой пузырь, который «не видел» мочи на протяжении долгого времени, восстанавливает свою функцию и емкость. Если необходимо, мочеточник может быть соединен с заранее сформированным кондуитом из толстой или тонкой кишки.

Существует несколько вариантов имплантации мочеточника донорской почки в мочевой пузырь реципинета. Один из наиболее распространенных методов экстравезикальная имплантация мочеточника по Lich-Gregoir. Сначала через катетер Фолея мочевой пузырь наполняют физиологическим раствором. Далее проводят диссекцию экстравезикальных тканей до мышечного слоя мочевого пузыря. После этого для формирования мышечного туннеля рассекают мышцу-детрузор на протяжении $2-4$ сантиметров и обнажают слизистую мочевого пузыря. Следующим этапом укорачивают мочеточник до необходимой длины, сохраняя адекватное кровоснабжение дистальной части и рассекают вдоль по нижней поверхности. Далее делают надрез слизистой мочевого пузыря и либо отдельными, либо непрерывным швом соединяют слизистую мочеточника со слизистой мочевого пузыря. Для анастомоза используется нить PDS 5/0 или 6/0. После того, как анастомоз завершен над ним ушивают мышцу-детрузор и, таким образом, формируют антирефлюксный механизм. Рассасывающуюся нить используют для профилактики камнеобразования. При гладком течении катетер Фолея удаляют на 4-7 послеоперационные сутки. 
С целью дренирования крови, мочи или лимфы в забрюшинное пространство через небольшую контрапертуру должна быть установлена дренажная трубка. Для снижения риска развития раневой инфекции более предпочтительна закрытая дренажная система типа Jackson- Pratt. Дренирование раны в раннем послеоперационном периоде позволяет снизить частоту образования лимфоцеле. Обычно дренажную трубку удаляют, когда количество отделяемого по ней по ней менее 100 мл в сутки.

\section{Хирургические особенности у детей}

Урологические расстройства и аномалии более чем в трети случаев является причиной терминальной почечной недостаточности у детей. Поэтому особенно важно исследовать функцию мочевого пузыря у детей с мочевыми инфекциями в анамнезе или у имеющих аномалии развития мочевыводящей системы. Реконструктивные операции должны выполняться с учетом возможной в будущем трансплантации почки. Родители и дети должны быть психологически подготовлены к периодическим катетеризациям, которые могут потребоваться после операции.

Хирургическая техника пересадки почки детям весом $20-25$ кг не отличается от трансплантации взрослым. Если до пересадки выполнялись реконструктивные вмешательства на мочевом пузыре, например, его увеличение или операция Митрофанова, то сложность трансплантации многократно возрастает. Для предотвращения послеоперационных осложнений надо тщательно выбрать положение трансплантата и метод имплантации мочеточника. Детям, вес которых меньше 20 кг пересаживают почки от взрослых доноров, так как трансплантация почки от аналогичных по антропометрическим параметрам доноров детского возраста сопряжена с рядом технических трудностей. В случае совсем маленьких реципиентов вену трансплантата анастомозируют с нижней полой веной реципиента, а артерию вшивают в аорту при этом наилучшее положение донорской почки - правая половина брюшной полости. У детей весом 10 - 12 кг при трансплантации может быть использован экстраперитонеальный доступ. Правая сторона предпочтительнее, так как выделение общих подвздошных сосудов в этом случае проще. Если вес реципиента меньше 10 кг выполняют срединный трансабдоминальный доступ. Для доступа к сосудам мобилизуют слепую кишку и трансплантат размещают позади нее. Также, чтобы освободить место для трансплантата, выполняется правосторонняя нефрэктомия собственной почки. До трансплантации, пациентам с рефрактерной артериальной гипертензией выполняют билатеральную нефрэктомию. Перед формированием неоуретероцистоанастомоза мочеточник трансплантата проводится над мочевым пузырем забрюшинно, что позволяет при 
возможных урологических осложнениях проводить повторные операции на мочеточнике без лапаротомии.

\section{Рекомендации}

- На этапах подготовки трансплантата, а также в ходе самой трансплантации следует проводить эффективный гемо- и лимфостаз (II-B);

- Перед формированием сосудистых анастомозов следует убедиться в отсутствии возможных разрывов интимы (II-B);

- Рекомендуется избегать перегиба почечной артерии и натяжения в области анастомозов (II-B);

- Места сосудистых анастомозов должны соответствовать длине сосудов трансплантата (II-B);

- Рекомендуется формировать широкий венозный анастомоз (II-B);

- Рекомендуется использовать короткий мочеточник и сохранять околомочеточниковую жировую клетчатку в области ворот почки (II-B);

- Следует избегать перевязки нижнеполюсной артерии в связи с риском некроза паренхимы и мочеточника (II-B);

- При формировании мочеточникового анастомоза возможно использование двойного Jобразный мочеточникового стента (II-B);

- Протяженность антирефлюксного туннеля при формировании пузырномочеточникового анастомоза должна составлять 3-4 см (II-B).

\section{3 Иное лечение}

Мониторинг пациентов после трансплантации почки в раннем послеоперационном периоде.

Неинвазивный:

- ЭКГ - постоянно, запись на ленту - 1 p/сут с последующим описанием в отделении функциональной диагностики

- Пульсоксиметрия - постоянно

- Частота дыхания - постоянно,

- АД - ежечасно. (Нельзя использовать руку с АВ- фистулой для измерения АД и пункций).

- Почасовое измерение диуреза. При нарушении оттока мочи, макрогематурии промывать физиологическим раствором под контролем хирурга-трансплантолога.

- Контроль отделяемого из дренажей. При подозрении на наличие мочи или большой объем отделяемого - анализ содержимого дренажа на мочевину, креатинин, электролиты. 
- Контроль потребления жидкости per os.

- Подсчет баланса жидкостей каждые 6 часов.

Инвазивный:

- ЦВД - через 4 часа, при полиурии/ олигурии - ежечасно.

Лабораторный:

- Общий анализ крови - 1 p/сутки;

- Гемоглобин, эритроциты, тромбоциты - по необходимости, при подозрении на кровотечение;

- Биохимический анализ крови: о Белок, альбумин, билирубин, АСТ, АЛТ, ЩФ, ГГТП, амилаза, СРБ - ежедневно, Гликемия - 2 р/сут, при необходимости - профиль (больные сахарным диабетом, пожилые пациенты), Электролиты крови (калий, натрий, кальций, хлор) и мочевина, креатинин - ч/з 12ч, при полиурии или анурии возможно чаще;

- КЩС - ч/з 6 часов первые сутки и до восстановления функции почки, рутинно - ч/з $12 ч$

- Коагулограмма -1 p/сут;

- Содержание иммуносупрессанта в крови - ежедневно, до приема утренней дозы.

Инструментальный:

- УЗИ органов брюшной полости (трансплантата почки) - не реже1 p/сут;

- Рентгенография органов грудной клетки - в первые 12ч после операции, далее по показаниям;

- Биопсия почки - при отсроченной функции трансплантата более 7 сут.

Назначения

- Голод в первые 12 часов, далее при появлении перистальтики. Питье по требованию, преимущественно питьевая вода;

- Ингаляция увлажненного кислорода;

- Антибактериальная терапия;

Цефалоспорин III/ IV и/или другие антибиотики в зависимости от исходного бактериального пейзажа и внутрибольничной флоры

- Контроль посевов крови, мочи, раны;

- Противогрибковая терапия;

- Профилактика пневмоцистной пневмонии;

- Противовирусная профилактика;

- Ганцикловир или Валганцикловир - требуется коррекция дозы в зависимости от СКФ. 
- Анальгезия наркотические и ненаркотические аналгетики по показаниям, НПВС противопоказаны;

- Гастропротекция ингибиторы протонной помпы в сочетании с Н2-блокаторами;

- Стимуляция диуреза;

При олигурии в качестве диагностического приема лазикс 40 - 60 мг, суточная доза до 200 мг.- Гипотензивные препараты

Использовать дооперационную схему препаратов под тщательным контролем АД. Опасность гипотензии (риск острого канальцевого некроза) !

1. Показания к гемодиализу:

a) $\mathrm{pH}<7,2$;

b) Гиперкалиемия более 6,5 ммоль/л;

с) Мочевина более 30ммоль/л, креатинин более 500 ммоль/л;

d) Анурия/ олигурия (диурез менее 0,5 мл/кг/ч) с гипергидратацией (прибавка к сухой массе тела более $8 \%$;

е) Признаки гипергидратации (отек легких), острый гидроперикард. Рекомендации

- Измерять объем мочи каждые 1-2 часа по крайней мере в течение 24 часов после трансплантации, далее ежедневно до стабилизации функции трансплантата (II-B);

- Измерять креатинин сыворотки по крайней мере:

1. ежедневно до выписки из больницы;

2. от 2 до 3 раз за неделю в течение 2-4 недель;

3. еженедельно со 2-ого по 3-й месяца;

4. каждые 2 недели для периода с 4 по 6 месяц;

5. ежемесячно для периода с 7 по 12 месяц • каждые 2-3 месяца впоследствии (II-B).

- Проводить измерения экскреции белка в моче по крайней мере: • еженедельно в первый месяц для определения базового уровня каждые 3 месяца в течение первого года ежегодно впоследствии;

- Выполнять УЗИ почечного трансплантата в рамки комплекса оценки дисфункции трансплантата;

- Проводить биопсию трансплантированной почки при наличии стойкого необъяснимого увеличения креатинина в сыворотке;

- Проводить биопсию трансплантированной почки, если креатинин в сыворотке не вернулся к базовому уровню после лечения острого отторжения. (II-B);

- Проводить биопсию трансплантированной почки каждые 7-10 дней при отсроченной функции; 
- Проводить биопсию трансплантированной почки, если предполагается, что функция почки не нормализуется в течение первых 1-2 месяцев после трансплантации;

- Проводить биопсию трансплантированной почки, когда имеется вновь выявленнная протеинурия $\geq 3.0$ г/л после трансплантации;

Иммуносупрессия после трансплантации почки.

Соответственно тому, что иммунологический ответ выражен максимально в течение ближайшего посттрансплантационного периода и затем обычно ослабевает, весь период иммуносупрессии после пересадки любого органа и, в частности, почки может быть разделен на два этапа — начальной и поддерживающей иммуносупрессии.

Начальная иммуносупрессия охватывает первые 3 мес после трансплантации, для которых характерны неустойчивая функция трансплантата и повышенная аллореактивность с максимальной вероятностью кризов отторжения. Задачей иммуносупрессии в этот период является предупреждение и лечение раннего отторжения при минимальном риске дополнительных повреждений уже исходно пострадавшего в реультате ишемии/реперфузии донорского органа. Тактика иммуносупрессивной терапии также должна быть направлена на снижение риска других серьезных, в первую очередь, инфекционных осложнений. Начальная иммуносупрессия состоит из индукционной и базисной (обязательной) терапии.

Выбор протокола начальной иммуносупрессивной терапии основывается на оценке иммунологического статуса реципиента и особенностей почечного трансплантата $[12,13]$. Особый подход c применением предтрансплантационной подготовки, включая иммуносупрессию, требуется к сенсибилизированным реципиентам крайне высокого иммунологического риска и при выполнении $\mathrm{AB} 0$-несовместимой трансплантации почки (протоколы предоперационной десенсибилизации).

Поддерживающая иммуносупрессия может быть разделена на два подпериода. Первый из них, относительно короткий (до 1 года), может быть обозначен как период ранней поддерживающей терапии, когда постепенно планово снижаются дозы иммунодепрессантов. Второй — период продолжающейся на протяжении всего срока функционирования пересаженной почки поддерживающей иммуносупрессии, когда уровень иммуносупрессии относительно стабилен и достаточен для предупреждения отторжения при минимизации риска ее осложнений. В этот период в связи с развитием дисфункции трансплантата может потребоваться изменение режима иммуносупрессии [14,15].

Начальная иммуносупрессия после трансплантации почки. 
Современные начальные иммуносупрессивные протоколы состоят из глюкокртикоидов, ингибитора кальциневрина, дополнительного препарата (трехкомпонентный протокол) и, возможно, индукции антителами (таблица 2)

\begin{tabular}{|c|c|}
\hline Класс препарата & Варьируемые параметры \\
\hline Ингибитор кальциневрина & Препараты: циклоспорин, такролимус \\
\hline Глюкокортикоиды & Дозы и режимы применения \\
\hline $\begin{array}{l}\text { Дополнительные } \quad \text { компоненты } \\
\text { иммуносупрессии }\end{array}$ & $\begin{array}{lcc}\text { Препараты: } & \text { микофенолаты, } & \text { ингибиторы } \\
\text { пролиферативного сигнала, азатиоприн } & \end{array}$ \\
\hline $\begin{array}{l}\text { Препараты } \\
\text { индукции }\end{array}$ & $\begin{array}{lc}\text { Лимфоцит-истощающие } & \text { поликлональные } \\
\text { (антитимоцитарные } & \text { глобулины) } \\
\text { лимфоцитнеистощающие моноклональные антитела }\end{array}$ \\
\hline
\end{tabular}

Таблица 2. Классы иммуносупрессивных препаратов

Острое отторжение почечного трансплантата.

Ни один из применяемых режимов иммуносупрессии не исключает развития отторжения, вероятность которого наиболее высока в первые 3 мес после трансплантации. Острое отторжение представляет собой результат иммунного ответа реципиента на антигены донора. Данное состояние следует заподозрить при резком повышении уровня креатинина (на 20-25\% от исходного уровня) в сочетании со снижением мочеотделения, уплотнением и болезненностью трансплантата, а также лихорадкой. Представленные клинические симптомы обладают низкой чувствительностью и специфичностью и были характерны для ранее использовавшихся схем иммуносупрессии. По этой причине на первом этапе должны быть исключены другие причины дисфункции почечного трансплантата (сосудистые, урологические), а для подтверждения острого отторжения обязательно выполнение пункционной биопсии. Следует отметить, что в идеале биопсия всегда должна предшествовать лечению, поскольку это позволяет избежать гипердиагностики острого отторжения.

\section{Лечение первого эпизода отторжения.}

Первый эпизод острого отторжения в большинстве случаев носит характер острого клеточного отторжения и соответствует Banff I-II, чувствительного к глюкокортикоидам. Антитимоцитарные антитела позволяют купировать более 95\% первых эпизодов отторжения. Несмотря на это, большинство протоколов предполагают в качестве терапии первой линии лечения острого отторжения пульс-терапию глюкокортикоидами. Это связано с большим удобством такой терапии, меньшими рисками развития побочных эффектов и меньшей стоимостью. 
Высокодозная пульс-терапия глюкокортикоидами внутривенно позволяет купировать 75- 80\% эпизодов отторжения. Существуют несколько схем пульс-терапии, но нет убедительных доказательств того, что высокодозные внутривенные режимы (500-1000 мг,однократно метилпреднизолона в течение 3 дней) более эффективны, чем высокодозные пероральные (120-250 мг преднизолона в течение 3-5 дней). Однако с точки зрения безопасности и переносимости терапии предпочтительно использовать метилпреднизолон в виде внутривенной инфузии в течение 30-60 мин. Поддерживающая доза глюкокортикоидов может быть сохранена на прежнем уровне после завершения пульс-терапии, хотя некоторые протоколы предусматривают еe повышение с последующим быстрым снижением. He показано постоянное повышение поддерживающей дозы глюкокортикоидов. Во время и после пульс-терапии оправданно возобновление профилактики ко-тримоксазолом.

Эффективность пульс-терапии оценивается на 2-3-и сутки лечения по динамике восстановления уровня креатинина. Считается, что на 5-е сутки после начала лечения уровень креатинина должен вернуться к исходному уровню или даже ниже от начала эпизода острого отторжения. Одновременно с проводимой терапией необходимо убедиться, что концентрация ингибиторов кальциневрина находится в пределах терапевтического диапазона. Если данное условие не соблюдено, необходима коррекция дозы препарата. Доза микофенолатов не должна быть ниже рекомендуемой. При развитии эпизода острого отторжения на фоне адекватной концентрации циклоспорина можно рассмотреть конверсию на такролимус. При отсутствии эффекта от лечения рекомендуется обязательное выполнение повторной пункционной биопсии на 4-5 сутки от начала лечения.

\section{Лечение повторного и стероидрезистентного отторжения.}

Метод выбора при терапии стероидрезистентного тяжелого клеточного отторжения (Banff IIB-III) — назначение антител [16]. Повторный эпизод острого отторжения представляет собой, как правило, тяжелое стероидрезистентное острое клеточное отторжение (Banff IIB), требующее назначения препаратов поликлональных антител. Приблизительно в $50 \%$ случаев обнаруживаются признаки острого гуморального отторжения. Развитие повторного отторжения сопровождается ухудшением отдаленного прогноза для выживаемости трансплантата.

Повторная пульс-терапия глюкокортикоидами может быть эффективной в лечении острых отторжений, однако назначать более двух курсов пульс-терапии перед применением антител не следует. Многие протоколы предполагают лечение антителами 
при всех повторных отторжениях, кроме тех, которые протекают благоприятно или развиваются как минимум через несколько недель после первого эпизода.

Рекомендуется начинать лечение антителами сразу, если не получено немедленного ответа на пульс-терапию, другие протоколы предлагают ожидать в течение несколько дней [17]. Если почечная функция быстро ухудшается, несмотря на пульстерапию, следует немедленно начинать лечение антитимоцитарным иммуноглобулином.

Дозы, в которых антитимоцитарный глобулин применяется в лечении отторжения, могут быть выше по сравнению с индукционными, а длительность лечения должна составлять не менее 5-7 дней. В течение курса необходим контроль гематологических показателей и профилактическое применение ганцикловира в течение 2-3 нед. Перевод с циклоспорина на такролимус или добавление микофенолатов у пациентов, которые раньше не получали их, также могут быть показаны после повторных эпизодов отторжения.

\section{Лечение гуморального (антитело-опосредованного отторжения).}

Термин «рефрактерное отторжение» применяется для определения отторжения, продолжающегося, несмотря на лечение глюкокортикоидами и антителами. Чаще всего оно имеет гуморальную природу. Лечение таких пациентов крайне сложно. Повторные курсы лечения истощающими антителами позволяют сохранить функцию трансплантата у 40-50\%. Когда принимается решение о начале второго курса терапии антителами, следует взвешенно оценить тяжесть и потенциальную обратимость отторжения по данным биопсии, риски развития инфекционных осложнений и малигнизации, которые существенно повышаются в результате массивной противокризовой терапии, особенно если два курса назначаются с небольшим интервалом.

Маркером активации системы комплемента является образование $\mathrm{C} 4 \mathrm{~d}$ фрагмента комплемента, не имеющего собственной функциональной активности, но ковалентно связывающегося с тканями почки. Показано, что свечение C4d в стенке перитубулярных капилляров тесно коррелирует с появлением анти-донорских антител в сыворотке пациента. Таким образом, острое гуморальное отторжение может быть диагностировано и считается достоверным при наличии четырех критериев:

- ухудшение почечной функции;

- фиксация C4d в стенке перитубулярных капилляров;

- гистологические признаки повреждения почечной ткани;

- идентификация донор-специфических анти-HLA антител.

При наличии лишь двух из перечисленных критериев диагноз считается вероятным, но не достоверным. 


\section{Реабилитация}

Поддерживающая терапия должна обеспечивать максимальную продолжительность жизни реципиента с функционирующим трансплантатом, что определяется адекватностью подавления аллоиммунного ответа, с одной стороны, и минимизацией риска побочных эффектов иммунодепрессантов, с другой стороны. После успешной трансплантации почки поддерживающая иммуносупрессивная терапия в подавляющем большинстве случаев включает три компонента, причем ее базисным препаратом, как правило, является ингибитор кальциневрина (циклоспорин или такролимус) [20], в сочетании с микофенолатами [19], реже азатиоприном, и глюкокортикоидами в минимальной дозе. В последние годы для поддерживающей иммуносупрессии применяются также ингибиторы пролиферативного сигнала (ингибиторы mTOR) [18].

В поздний период (более 6 мес) после пересадки почки концентрацию такролимуса обычно поддерживают на уровне 6-9 нг/мл. В сроки более 12 мес после трансплантации у пациентов с низким функциональным резервом трансплантата, малой массой функционирующих нефронов или особой чувствительностью к нефротоксическому действию такролимуса концентрацию можно снизить до 3-5 нг/мл. При этом также важно помнить о риске отторжения и при необходимости увеличить дозу сопутствующих препаратов.

\section{Рекомендации}

- Рекомендуется начинать введение комплекса иммуносупрессивных препаратов до или во время трансплантации почки (II-A);

- Рекомендуется включать индукционную терапию биологическими агентами как часть стартового комплекса иммуносупрессивных препаратов (II-A);

- Рекомендуется чтобы IL2-RA были первоочередным средством в индукционной терапии (II-B);

- Рекомендуется использовать лимфоцит-истощающие агенты вместо IL2-RA для реципиентов высокого иммунологического риска (II-B);

- Рекомендуется использовать комбинацию иммуносупрессивных лекарственных препаратов как поддерживающую терапию, включая CNI и антипролиферативный агент, с приемом или без приема кортикостероидов (II-B);

- Применять такролимус как первоочередной ингибитор кальциневрина (II-C);

- Применять микофенолаты как первоочередной антипролиферативный агент (II-C); 
- Использовать самые низкие из запланированных доз иммуносупрессивных лекарственных препаратов к окончанию периода в 2-4 месяца после трансплантации, если не было острого отторжения (II-C);

- Предпочтительно продолжение приема ингибиторов кальциневрина, чем отмена их (II-B);

- Если преднизон используется дольше, чем в течение первой недели после трансплантации, предпочтительно скорее продолжать прием преднизона, чем отменить его (II-C);

- Рекомендуется измерять уровень ИКН в крови и предлагаем делать измерения, по крайней мере, в следующем режиме:

a) через день в течение ближайшего послеоперационного периода до тех пор, пока целевые уровни не будут достигнуты (II-C);

b) изменения в назначенных препаратах или состоянии пациента может повлиять на уровни концентрации препаратов в крови (II-C);

c) ухудшение функции почек может свидетельствовать о нефротоксичности или отторжении (II-C);

- Целесообразно проводить мониторинг уровня mTORi (II-C);

- Необходимо проведение биопсии перед началом лечения острого отторжения, за исключением случаев, когда биопсия противопоказана или невозможна в ближайшее время (II-A);

- Целесообразно проводить лечение субклинического и пограничного острого отторжения (II-C);

- Рекомендуется применять кортикостероиды для первоначального лечения острого клеточного отторжения (II-A);

- Рекомендуется добавлять или возобновлять назначение преднизона в качестве поддерживающей терапии для пациентов, которые не получают стероиды, но имеют эпизоды отторжения (II-A);

- Необходимо использовать лимфоцит-истощающие антитела для лечения острого клеточного отторжения, когда нет ответа на лечение кортикостероидами, а также для рецидивирующего острого клеточного отторжения (II-C);

- Лечение антитело-опосредованного острого отторжения возможно путем одной либо нескольких из следующих схем, с применением кортикостероидов или без них:

a) плазмаферез;

b) внутривенное введение иммуноглобулинов; 
с) анти-CD20 моноклональные антитела;

d) лимфоцит-истощающие антитела.

- Для пациентов, которые имеют эпизоды отторжения рекомендуется добавлять микофенолат (II-C). 


\section{Профилактика и диспансерное наблюдение}

В послеоперационном периоде всем реципиентам рекомендуется регулярная оценка функционального состояния почечного трансплантата. Динамическое обследование должно осуществляться персональным лечащим врачом. После выписки из стационара реципиент пожизненно остается под наблюдением центра трансплантации.

Рекомендации:

- оценка почечной функции: ежемесячно в первые 3 месяца, 1 раз в 3 месяца в течение первого года, далее ежегодно;

- в случае дисфункции почечного трансплантата показано внеочередное обследование;

- в первые 3 месяца ограничение физической нагрузки с целью профилактики грыжеобразования;

- мониторинг возврата основного заболевания почек.

Гистологические признаки рецидива исходного заболевания нередко отмечаются в трансплантатах. Несмотря на возможность рецидивирования некоторых заболеваний почек, суммарный 10-летний риск потери трансплантата от возвратного заболевания не превышает $10 \%$. Более высокая частота наблюдений возврата заболеваний при трансплантации от живых родственных доноров, особенно раннее их развитие, требует дальнейшего изучения и обсуждения.

Заболевания почек, характеризующиеся высокой частотой рецидивирования, приводящей к ранней потере трансплантата, являются противопоказанием к пересадке почки. К соответствующей группе нозологий относятся болезнь Вальденстрема, первичный оксалоз, а также антигломерулярные антительные реакции (сопровождающиеся образованием антител к базальным мембранам гломерул). Тем не менее, в ряде ситуаций выполнение трансплантации возможно.

В отношении пациентов с первичным оксалозом рекомендуется комбинированная трансплантация «печень-почка». В отношении пациентов с амилоидозом или болезнью Вальденстрема не имеется специальных рекомендаций (в связи с низкой частотой встречаемости).

При наличии у пациентов системных заболеваний (например, системной красной волчанки, васкулита, гемолитико-уремического синдрома) рекомендуется лечение фонового заболевания с целью достижения фазы ремиссии на момент трансплантации

В отношении большинства пациентов с гломерулонефритом не имеется специальных рекомендаций. После выполнения трансплантации могут отмечаться случаи рецидивирования фокального и сегментарного гломерулосклероза; лечение должно включать в себя плазмаферез и/или анти-CD20-антительные препараты (ритуксимаб). При потере предыдущего трансплантата вследствие возвратного гломерулонефрита (особенно при рецидивировании фокального и сегментарного гломерулосклероза) пациент должен быть проинформирован о высоком риске неудачи повторной транс- плантации. Тем не менее, успешные исходы возможны и у пациентов данной категории.

Пациенты, которым ранее выполнялась трансплантация.

При наличии в анамнезе потери функции почечного трансплантата рекомендуется тщательное обследование пациента на предмет злокачественных новообразований, 
сердечно-сосудистых заболеваний и повышенного иммунологического риска (наличие антител к первому трансплантату). Рекомендуемой тактикой в отношении пациентов данной категории является отмена иммуносупрессии. При появлении патологических проявлений со стороны нефункционирующего трансплантата рекомендуется незамедлительно выполнить нефрэктомию. В качестве альтернативного варианта может рассматриваться эмболизация сосудов трансплантата. Тем не менее, профилактическая трансплантатэктомия не служит гарантией от последующих иммунных реакций. При подборе второго органа рекомендуется избегать повторных аллогенных несовместимостей.

Реципиентам других органов $\mathrm{c}$ развившейся терминальной почечной недостаточностью выполнение пересадки почки возможно, но сопровождается повышенным риском осложнений. На этапе предоперационной подготовки рекомендуется тщательное обследование пациента на предмет злокачественных новообразований, сердечно-сосудистых заболеваний и повышенного иммунологического риска, а также оценки функции ранее пересаженного органа для определения целесообразности комбинированной трансплантации.

Рекомендации

- Для увеличения показателей выживания трансплантатов и пациентов после выполненной трансплантации целесообразно заблаговременное и тщательное обследование пациентов в предоперационном периоде (II-B);

- При наличии заболеваний мочеполовой системы обязательным условием является тщательное обследование пациента перед выполнением трансплантации почки (первостепенное значение имеет оценка состояния уродинамики) (II-C);

- При наличии аутосомно-доминантного синдрома поликистозных почек, а также при наличии определенных условий (недостаточное пространство для трансплантации, наличие осложнений, хронических инфекционных процессов, подозрений на злокачественные новообразования) имеются показания для предтрансплантационной или одномоментной нефрэктомии (II-C);

- Активный инфекционный процесс, который может представлять собой угрозу для жизни реципиента после проведенной трансплантации, является противопоказанием к трансплантации(II-B);

- Bce кандидаты для трансплантации должны пройти скрининг с целью идентификации вирусных и бактериальных инфекций. В частности, необходимо выявить инфекционные процессы, вызванные такими возбуди телями, как HBV, HCV, ВИЧ, ЦМВ и туберкулез (сбор анамнеза и обзорная рентгенография грудной клетки) (II-B);

- С целью профилактики послеоперационных осложнений показано выявление и лечение фоновых заболеваний перед выполнением трансплантации (II-C);

- В отношении пациентов с высоким риском кардиальной патологии настоятельно рекомендуется детальное обследование с целью исключения ишемической болезни сердца (II-B);

- При наличии показаний до проведения трансплантации рекомендуется выполнение реваскуляризации (как хирургической, так и коронарной ангиопластики) (IIB); 
- При наличии тяжелых сопутствующих заболеваний или при неадекватном поведении (некомплаентности) потенциального реципиента показано тщательное индивидуальное психологическое обследование (II-B);

- До проведения трансплантации показано тщательное индивидуальное обследование потенциального реципиента с целью выявления атеросклеротического поражения тазовых, периферических и церебральных артерий. Рекомендовано использовать весь необходимый арсенал лечебно- диагностических мероприятий (II-B);

- Наличие сахарного диабета не является противопоказанием к трансплантации органов. Тем не менее, заблаговременно до выполнения трансплантации целесообразно детальное обследование пациентов (II-B);

- Ожирение не является противопоказанием к трансплантации органов. Тем не менее, до выполнения трансплантации целесообразно детальное обследование пациентов и лечение, направленное на уменьшение массы тела (II-C);

- С целью профилактики ранних послеоперационных тромботических осложнений показано тщательное изучение состояния системы свертывания крови перед выполнением трансплантации у пациентов повышенного риска (II-C);

- Несмотря на то, что сам по себе возраст не является противопоказанием к выполнению трансплантации, целесообразно тщательно взвесить риски и ожидаемую пользу; пациенты должны быть информированы об увеличении вероятности возникновения послеоперационных осложнений в связи с возрастом (II-B);

- Случаи рецидивирования исходного заболевания почек достаточно часты,однако потери трансплантата при этом встречаются редко (II-C);

- Лишь при некоторых редко встречающихся нозологических формах (характеризующихся высокой частотой рецидивирования) трансплантация противопоказана (II-C);

- При наличии риска рецидивирования исходной патологии почек пациент должен быть об этом проинформирован (II-C) ;

- При планировании повторной трансплантации, а также при наличии в анамнезе экстраренальной трансплантации рекомендуется оценить степень иммунологического риска (в том числе провести тщательный анализ титров анти-HLA-антител) (II-C). 


\section{Критерии оценки качества медицинской помощи}

\begin{tabular}{|c|c|c|c|}
\hline № III. & Критерий & \begin{tabular}{|l} 
Вид \\
критерия
\end{tabular} & $\begin{array}{l}\text { Этап мед. } \\
\text { помощи }\end{array}$ \\
\hline 1 & $\begin{array}{l}\text { Осмотр (консультация) лечащего врача - } \\
\text { ежедневно в стационаре }\end{array}$ & I & C \\
\hline 2 & $\begin{array}{l}\text { Клинические (инструментальные, лабораторные) } \\
\text { обследования, необходимые для неинвазивной } \\
\text { оценки функции почечного трансплантата }\end{array}$ & I & C \\
\hline 3 & $\begin{array}{l}\text { Консультация ведущего специалиста } \\
\text { (профессора) }\end{array}$ & I & C \\
\hline 4 & $\begin{array}{l}\text { Ультразвуковое исследование в течение первых } \\
7 \text { дней после выполнения трансплантации почки }\end{array}$ & I & C \\
\hline 5 & $\begin{array}{l}\text { Определение концентрации такролимуса или } \\
\text { циклоспорина в крови не реже } 2 \text { раз в неделю в } \\
\text { течение первого месяца после операции } \\
\text { трансплантации почки }\end{array}$ & I & C \\
\hline 6 & $\begin{array}{l}\text { Пункционная биопсия при дисфункции } \\
\text { трансплантата }\end{array}$ & I & $\mathrm{C}$ \\
\hline 6 & $\begin{array}{l}\text { Индивидуальный подбор комбинированной } \\
\text { иммуносупрессивной терапии, а также } \\
\text { лекарственных средств для профилактики } \\
\text { инфекционных осложнений, побочных действий } \\
\text { лекарственных средств с узким терапевтическим } \\
\text { диапазоном и средств, улучшающих отдаленный } \\
\text { прогноз }\end{array}$ & I & C \\
\hline
\end{tabular}




\section{Список литературы}

1. Иммуносупрессия при трансплантации солидных органов / Под ред. С.В. Готье. М. - Тверь: ООО «ИздательствоТриада», 2011; с.382.

2. Kidney transplantation: principles and practice. 6th ed. / Ed. by Sir Peter J. Morris and Stuart J. Knechtle // Philadelphia: Elsevier Saunders, 2008.

3 Gore J.L., Pham P.T., Danovitch G.M. et al. Obesity and outcome following renal transplantation. Am J Transplant, 2006; 6: p.357-363.

4. Данович Габриэль М. Трансплантация почки / Пер. с англ. под ред. Я.Г. Мойсюка. - М: ГЭОТАР-Медиа, 2013; с.848.

5. Kable T., Alcaraz A., Budde K., Humke U., Karam G., Lucan M., Nicita G., Susal C. Трансплантация почки: Клинические рекомендации Европейской Ассоциации Урологов, 2010 / Перевод с англ под ред. Д.В. Перлина. - М.: АБВ-Пресс, 2010; с.100.

6. KDIGO clinical practice guideline for the care of kidney transplant recipients. Am J Transplant, 2009; 9 Suppl : p.51-155.

7. Kasiske B.L., Maclean J.R., Snyder J.J. Acute myocardial infarction and kidney transplantation. J Am Soc Nephrol, 2006; 17: p.900-907.

8. Morrissey P.E., Flynn M.L., Lin S. Medication noncompliance and its implications in transplant recipients. Drugs, 2007; 67: p.1463-1481.

9. Kurtkoti J., Sakhuja V., Sud K. et al. The utility of 1- and 3-month protocol biopsies on renal allograft function: A randomized controlled study. Am J Transplan,t 2008; 8: 317323.

10. Almeras C., Foulongne V., Garrigue V. et al. Does reduction in immunosuppression in viremic patients prevent BK virus nephropathy in de novo renal transplant recipients? A prospective study. Transplantation, 2008; 85: 1099-1104.

11. Мойсюк Я.Г., Столяревич Е.С., Томилина Н.А. Болезнь почечного трансплантата / Нефрология: национальное руководство // под ред. Н.А. Мухина. - М.: ГЭОТАР- Медиа, 2009; с.588 (Серия «Национальные руководства»).

12. Brennan D.C., Daller J.A., Lake K.D. et al. Rabbit antithymocyte globulin versus basiliximab in renal transplantation. N Engl JMed, 2006; 355: p.1967-1977.

13. Webster A.C., Woodroffe R.C., Taylor R.S. et al. Tacrolimus versus ciclosporin as primary immunosuppression for kidney transplant recipients: Meta-analysis and meta-regression of randomized trial data. BMJ, 2005; 331: 810.

14 Ekberg H., Tedesco-Silva H., Demirbas A. et al. Reduced exposure to calcineurin inhibitors in renal transplantation. N Engl J Med, 2007; 357: 2562-2575. 
15. Rostaing L., Cantarovich D., Mourad G. et al. Corticosteroid-free immunosuppression with tacrolimus, mycophenolate mofetil, and daclizumab induction in renal transplantation. Transplantation, 2005; 79: 807-814.

16. Solez K., Colvin R.B., Racusen L.C. et al. Banff '05 Meeting Report: Differential diagnosis of chronic allograft injury and elimination of chronic allograft nephropathy ('CAN'). Am J Transplant, 2007; 7: 518-526.

17. Webster A.C., Pankhurst T., Rinaldi F. et al. Monoclonal and polyclonal antibody therapy for treating acute rejection in kidney transplant recipients: A systematic review of randomized trial data. Transplantation, 2006; 81: 953-965.

18. Nashan B. Review of the proliferation inhibitor everolimus. ExpertOpin Investig Drugs, 2002; 11: 1845-1857.

19. Knight S.R., Morris P.J. Does the evidence support the use of mycophenolate mofetil therapeutic drug monitoring in clinical practice? A systematic review. Transplantation, 2008; 85: p.1675-1685.

20. Kyllonen L.E., Salmela K.T.. Early cyclosporine C0 and C2 monitoring in de novo kidney transplant patients: A prospective randomized single-center pilot study. Transplantation, 2006; 81: 1010-1015. 


\section{Приложение А1. Состав Рабочей группы}

\begin{tabular}{|c|c|c|c|c|c|}
\hline № пா & ФИО & $\begin{array}{l}\text { Ученая } \\
\text { степень }\end{array}$ & $\begin{array}{l}\text { Ученое } \\
\text { звание }\end{array}$ & $\begin{array}{l}\text { Почетные звания } \\
\text { и награды }\end{array}$ & $\begin{array}{l}\text { Профессиональна } \\
\text { я ассоциация }\end{array}$ \\
\hline 1 & $\begin{array}{l}\text { Арзуманов } \\
\text { Сергей } \\
\text { Викторович } \\
\end{array}$ & К.М.Н. & & & \multirow{17}{*}{$\begin{array}{l}\text { ОООТ "Российское } \\
\text { трансплантологиче } \\
\text { ское общество" }\end{array}$} \\
\hline 2 & $\begin{array}{l}\text { Бельских } \\
\text { Леонид } \\
\text { Владиславович }\end{array}$ & К.М.Н. & & & \\
\hline 3 & $\begin{array}{l}\text { Быков } \\
\text { Александр } \\
\text { Юрьевич } \\
\end{array}$ & к.М.Н. & & & \\
\hline 4 & $\begin{array}{l}\text { Валов Алексей } \\
\text { Леонидович } \\
\end{array}$ & д.м.н. & & & \\
\hline 5 & $\begin{array}{l}\text { Ватазин } \\
\text { Андрей } \\
\text { Владимирович } \\
\end{array}$ & д.м.н. & проф. & & \\
\hline 6 & $\begin{array}{l}\text { Галеев } \\
\text { Шамиль } \\
\text { Ринатович } \\
\end{array}$ & к.М.Н. & & & \\
\hline 7 & $\begin{array}{l}\text { Гичкун Ольга } \\
\text { Евгеньевна }\end{array}$ & К.М.Н. & & & \\
\hline 8 & $\begin{array}{l}\text { Готье Сергей } \\
\text { Владимирович }\end{array}$ & Д.м.н. & $\begin{array}{l}\text { проф., } \\
\text { акад. } \\
\text { РАН }\end{array}$ & $\begin{array}{l}\text { 3В,пр.Прав.РФ200 } \\
8,2014\end{array}$ & \\
\hline 9 & \begin{tabular}{|l} 
Загайнов \\
Владимир \\
Евгеньевич \\
\end{tabular} & д.м.н. & проф. & & \\
\hline 10 & $\begin{array}{l}\text { Климушева } \\
\text { Наталья } \\
\text { Федоровна } \\
\end{array}$ & К.М.Н. & & & \\
\hline 11 & $\begin{array}{l}\text { Милосердов } \\
\text { Игорь } \\
\text { Александрович } \\
\end{array}$ & к.М.н. & & & \\
\hline 12 & $\begin{array}{l}\text { Минина } \\
\text { Марина } \\
\text { Геннадьевна } \\
\end{array}$ & д.м.н. & & пр.Прав.РФ2014 & \\
\hline 13 & $\begin{array}{l}\text { Николаев } \\
\text { Герман } \\
\text { Викторович } \\
\end{array}$ & К.М.Н. & & & \\
\hline 14 & $\begin{array}{l}\text { Перлин } \\
\text { Дмитрий } \\
\text { Владиславович } \\
\end{array}$ & Д.м.н. & проф. & & \\
\hline 15 & \begin{tabular}{|l|} 
Петрова \\
Наталья \\
Юрьевна \\
\end{tabular} & К.М.Н. & & & \\
\hline 16 & $\begin{array}{l}\text { Платонов } \\
\text { Вадим } \\
\text { Сергеевич } \\
\end{array}$ & к.М.н. & & & \\
\hline 17 & Попцов & Д.М.н. & проф. & пр.Прав.РФ2014 & \\
\hline
\end{tabular}




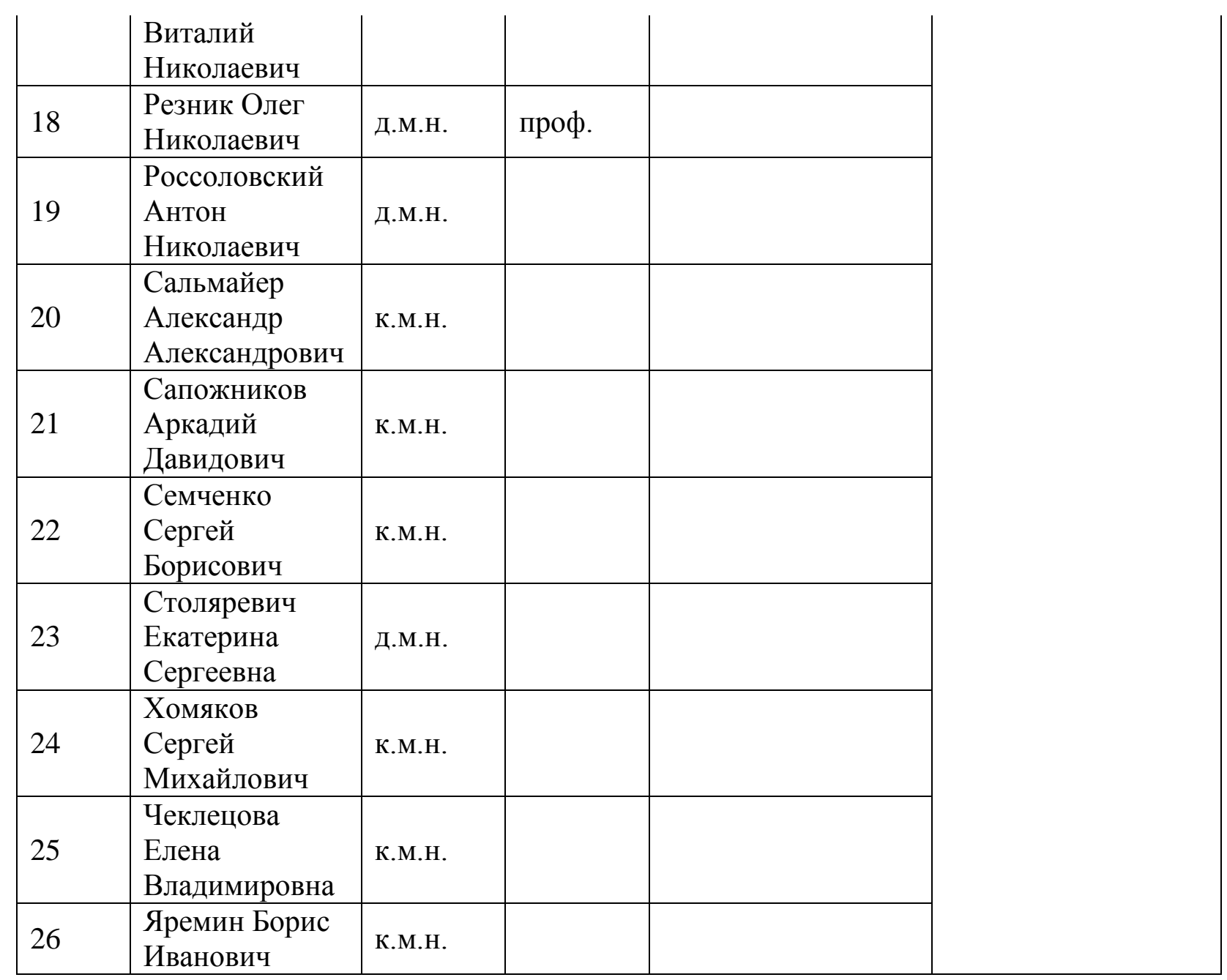




\section{Приложение A2. Методология разработки клинических рекомендаций Целевая аудитория данных клинических рекомендаций:}

Врачи следующих специальностей:

1. Терапия;

2. Хирургия;

3. Анестезиология-реаниматология;

4. Нефрология;

5. Общая врачебная практика;

6. Патологанатомия.

\section{Классификация рекомендаций и степени доказанности}

При создании данных клинических рекомендаций использовались приведенные ниже классификация рекомендаций и уровни достоверности доказательств (степени доказанности) - таблицы П1 и П2). Следует отметить, что с учетом специфики контингента больных хронической почечной недостаточностью большинство рекомендации имеет степень доказанности «С».

\section{Таблица П1. Классы рекомендаций}

Класс I: По данным клинических исследований и/или по общему мнению данный метод лечения или вмешательство полезны и эффективны

Класс II: Противоречивые данные и/или расхождение мнений по поводу пользы/эффективности предлагаемого метода лечения или вмешательства

Класс ІІа: Имеющиеся данные свидетельствуют в пользу эффективности метода лечения или вмешательства

Класс IIb: Польза/эффективность метода лечения или вмешательства установлены менее убедительно

Класс III: По данным клинических исследований или общему мнению метод лечения или вмешательство бесполезны / неэффективны и в некоторых случаях могут быть вредны

Таблица П2. Уровни достоверности доказательств (степени доказанности)

Степень А: доказательства получены в многочисленных рандомизированных клинических исследованиях или мета-анализах

Степень В: доказательства получены в единственном рандомизированном клиническом исследовании или крупных нерандомизированных исследованиях

Степень C: в основе рекомендации лежит общее мнение экспертов и/или результаты небольших исследований, ретроспективных исследований, регистров

\section{Порядок обновления клинических рекомендаций}

Национальные рекомендации по Трансплантация почки обновляются не реже одного раза в три года, утверждаются решением Координационного Совета общероссийской общественной организации трансплантологов «Российское трансплантологическое общество», рассматриваются и рекомендуются к утверждению Профильной комиссией по трансплантологии Минздрава России. 


\section{Приложение АЗ. Связанные документы}

Лечение больных хронической недостаточностью осуществляется в рамках законодательства Российской Федерации и представлен в следующих нормативных документах:

1. Федеральные законы РФ:

Федеральный закон от 21.11.2011 N 323-Ф3 (ред. от 26.04.2016) "Об основах охраны здоровья граждан в Российской Федерации", Статья 47. Донорство органов и тканей человека и их трансплантация (пересадка);

"О донорстве органов, частей органов человека и их трансплантации" (проект федерального закона).

2. Постановления Правительства РФ:

- "Об утверждении Правил определения момента смерти человека, в том числе критериев и процедуры установления смерти человека, Правил прекращения реанимационных мероприятий и формы протокола установления смерти человека" от 20 сентября 2012 г. № 950;

"О лицензировании медицинской деятельности (за исключением указанной деятельности, осуществляемой медицинскими организациями и другими организациями, входящими в частную систему здравоохранения, на территории инновационного центра "Сколково")" от 16 апреля 2012 г. № 291;

"О порядке финансового обеспечения медицинской деятельности, связанной с донорством органов человека в целях трансплантации (пересадки), за счет бюджетных ассигнований федерального бюджета" от 23 января 2016 г. № 33.

3. Приказы Минздрава (Минздравсоцразвития) России:

"Об утверждении Порядка оказания медицинской помощи по профилю "хирургия (трансплантация органов и (или) тканей человека)"" от 31 октября 2012 г. № 567н;

"Об утверждении Порядка оказания медицинской помощи взрослому населению по профилю "анестезиология и реаниматология" от 15 ноября 2012 г. № 919н;

- "Об утверждении Порядка оказания медицинской помощи больным с острыми нарушениями мозгового кровообращения" от 15 ноября 2012 г. № 928н;

- "Об утверждении Инструкции по констатации смерти человека на основании диагноза смерти мозга" от 20 декабря 2001 г. № 460; 
"О Порядке установления диагноза смерти мозга человека" от 25 декабря 2014 г. № 908н (вступил в силу с 1 января 2016 г.) ;

- "Об утверждении Инструкции по определению критериев и порядка определения момента смерти человека, прекращения реанимационных мероприятий" от 4 марта 2003 г. № 73;

"Об утверждении перечня учреждений здравоохранения, осуществляющих забор, заготовку и трансплантацию органов и (или) тканей человека" от 4 июня 2015 г. № 307н/4;

- "Об утверждении перечня объектов трансплантации" от 4 июня 2015 г. № 306н/3;

- "О медицинском заключении о необходимости трансплантации органов и (или) тканей человека" от 25 мая 2007 г. № 358;

- "Об утверждении перечня видов высокотехнологичной медицинской помощи" от 29 декабря 2012 г. № 1629н;

- Об утверждении Порядка оказания медицинской помощи взрослому населению по профилю «нефрология" от 18 января 2012г. 17н.

4. Международные акты:

- Руководящие принципы BO3 по трансплантации человеческих клеток, тканей и органов (WHA 63.22) ;

Стамбульская декларация о трансплантационном туризме и торговле органами, 2008г. 


\section{Приложение Б. Алгоритмы ведения пациента}

Алгоритмы выбора тактики лечения у больного с критической/декомпенсированной сердечной недостаточностью.

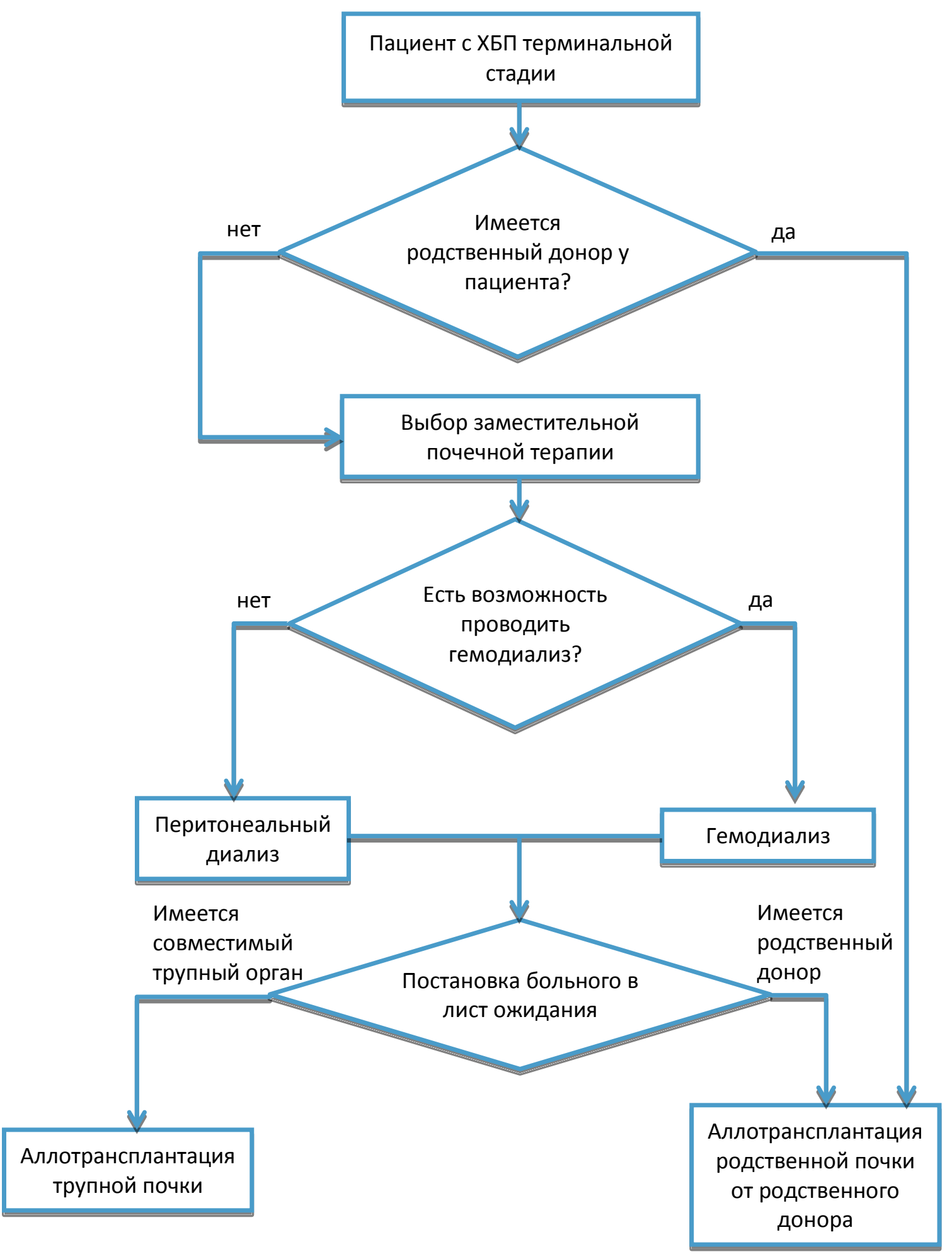

